\title{
Proliferation-dependent Changes in Release of Arachidonic Acid from Endothelial Cells
}

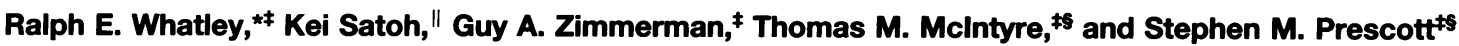 \\ *Veterans Affairs Medical Center, the Nora Eccles Harrison Cardiovascular Research and Training Institute, Salt Lake City, \\ Utah 84112; Departments of ${ }^{\ddagger}$ Medicine and ${ }^{8}$ Biochemistry, University of Utah School of Medicine, Salt Lake City, Utah 84112; \\ and "the Department of Pathological Physiology, Institute of Neurological Disease, Hirosaki University, Hirosaki 036, Japan
}

\begin{abstract}
Stimulation of endothelial cells resulted in release of arachidonic acid from phospholipids. The magnitude of this response decreased as the cells became confluent and the change coincided with a decrease in the percentage of cells in growth phases $\left(G_{2}+M\right)$; this was not a consequence of time in culture or a factor in the growth medium. Preconfluent cells released $\sim 30 \%$ of arachidonic acid; confluent cells released only $6 \%$. The decreasing release of arachidonic acid was demonstrated using metabolic labeling, mass measurements of arachidonic acid, and measurement of

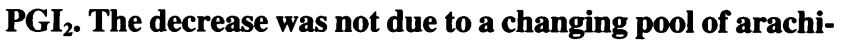
donic acid, and mass measurements showed no depletion of arachidonic acid. Release from each phospholipid and from each phospholipid class decreased with confluence. Conversion of confluent cells to the proliferative phenotype by mechanical wounding of the monolayer caused increased release of arachidonic acid. Potential mechanisms for these changes were investigated using assays of phospholipase activity. Phospholipase $A_{2}$ activity changed in concert with the alteration in release, a consequence of changes in phosphorylation of the enzyme. The increased release of arachidonic acid from preconfluent, actively dividing cells may have important physiologic implications and may help elucidate mechanisms regulating release of arachidonic acid. (J. Clin. Invest. 1994. 94:1889-1900.) Key words: arachidonic acid • phospholipid • endothelial cell • phospholipase • cyclooxygenase
\end{abstract}

\section{Introduction}

Oxidative metabolites of arachidonic acid (eicosanoids) are a diverse group of bioactive lipids which are produced in response to appropriate stimulation by a variety of cells, including endothelial cells (1-4). The synthesis and secretion of $\mathrm{PGI}_{2}$ and other arachidonic acid metabolites by endothelial cells are thought to modulate vascular tone and the interaction with blood cells (5-7). Thus, the regulation of arachidonic acid metabolism in endothelial cells has an important role in vascular physiology. In addition to these actions, recent work suggests that arachidonic acid metabolites, or more precisely metabolites of the cyclooxygenase pathway, play a role in proliferation and neo-

Address correspondence to Ralph E. Whatley, M.D., CVRTI; Bldg. 500, University of Utah, Salt Lake City, UT 84112.

Received for publication 22 November 1993 and in revised form 7 July 1994.

The Journal of Clinical Investigation, Inc.

Volume 94, November 1994, 1889-1900 plasia. This includes studies implicating eicosanoids in the regulation of growth in other cells $(8,9)$ and tissues, including colonic polyps and cancer of the colon $(10,11)$. One group has found evidence that arachidonic acid metabolites are synergistic with certain growth factors in mediating endothelial cell mitogenesis (12). In addition, studies from several laboratories have shown recently that cytokines cause expression of novel eicosanoid pathway enzymes, including a second, inducible, prostaglandin $\mathrm{H}_{2}$ synthetase found in several cell types, including endothelial cells (13). Many phenotypic changes occur in cultured endothelial cells as they progress from an actively dividing, preconfluent cell to a contact-inhibited monolayer. Several studies have shown that the ability of endothelial cells to produce $\mathrm{PGI}_{2}$ changes as the cells are maintained in culture, particularly with multiple passes $(1,14-16)$. Thus, there is evidence that arachidonic acid metabolism is in some way related to the growth state of endothelial cells in culture. Taken together, these data suggest that an arachidonic acid metabolite may regulate proliferation or play a role in unregulated proliferation.

Endothelial cells are a good model system for study of these issues because they can be cultured in highly purified populations, and arachidonic acid metabolism is under the control of well-characterized intracellular signals induced by a variety of agonists. The spectrum of eicosanoids produced varies among endothelial cell types, but, in macrovascular endothelial cells, the predominant product is $\mathrm{PGI}_{2}$. Synthesis of eicosanoids begins with the release of arachidonic acid from phospholipid stores $(17,18)$. This release does not occur constitutively but requires stimulation of the cells with specific agonists $(1,19$, 20). Arachidonic acid is stored as an esterified fatty acid in phospholipids, usually at the $s n-2$ position (21). Release of arachidonic acid upon stimulation is believed to occur by the action of phospholipase(s), usually by a phospholipase $\mathrm{A}_{2}\left(\mathrm{PLA}_{2}\right)^{1}$ that releases arachidonic acid directly, or in concert with a transacylase $(22,23)$. Alternatively, release can result from a phospholipase $\mathrm{C}$ that hydrolyzes the phospholipid to diacylglycerol, followed by diglyceride and monoglyceride lipases that release arachidonic acid. There is evidence for each of these pathways in several cell types $(7,24,25)$, and the relative contribution of each to total arachidonic acid release is not known. Similarly, the mechanisms that govern the activation of the phospholipase(s) are not completely understood. It is clear that a rise in intracellular calcium concentrations is necessary for release of arachidonic acid $(7,26)$ and that entry of extracellular calcium is necessary for a full response in most cell types (26). There is evidence in endothelial cells that phospholipases $\mathrm{C}$ and

1. Abbreviations used in this paper: GLC, gas liquid chromatography; PC, phosphatidylcholine; PE, phosphatidylethanolamine; PI, phosphatidylinositol; PI-PLC, PI-specific phospholipase C; PKC, protein kinase C; PL, phospholipase; PS, phosphatidylserine. 
D are activated concurrently with a rise in cellular calcium and $\mathrm{PGI}_{2}$ production $(7,27-29)$, but the contribution of these phospholipase activities to total arachidonic acid release is not known. Several groups have purified a cytoplasmic PLA $\mathrm{P}_{2}$ that is selective for arachidonic acid at the $s n-2$ position $(30-35)$. Moreover, this enzyme translocates to cell membranes and is activated in response to calcium concentrations that occur in the cytosol of stimulated cells $(31,33,35)$. These characteristics make it an attractive candidate for the activity responsible for the release of arachidonic acid from intact cells. Our previous work, and that by other investigators, suggested that PLA $\mathrm{A}_{2}$ activity in endothelial cells also is regulated, in part, by protein kinase C (PKC) (36-38).

Using the endothelial cell model, we have investigated growth-dependent alterations in arachidonic acid release and metabolism. In this work, we demonstrate that there is a dramatic decline in stimulated arachidonic acid release from phospholipids and the subsequent synthesis of $\mathrm{PGI}_{2}$ in cultured endothelial cells as they progress from an actively proliferating preconfluent state to a contact-inhibited, confluent monolayer. We find that this effect is consistent with a regulated, growth-dependent change in the activity of PLA $\mathrm{A}_{2}$, a process regulated by changes in phosphorylation of the enzyme. Moreover, the low release state appears to be the usual one in vivo.

\section{Methods}

Materials. Calcium ionophore A23187, di-C17 phosphatidylcholine, arachidonic acid, docosatetraenoic acid, potato acid phosphatase (type VII), phospholipase C (Bacillus cereus), and benzoic anhydride were purchased from Sigma Immunochemicals (St. Louis, MO). 6-keto- $\left[{ }^{3} \mathrm{H}\right]-$ prostaglandin $\mathrm{F}_{1 \alpha}(120 \mathrm{Ci} / \mathrm{mmol}), \quad \mathrm{L}-\alpha$-[myo-inositol-2- $\left.{ }^{3} \mathrm{H}(N)\right]$-phosphatidylinositol $(5-20 \mathrm{Ci} / \mathrm{mmol}), \quad$ L- $\alpha$-1-steroyl-2- $\left[{ }^{3} \mathrm{H}\right]$ arachidonoyl phosphatidylcholine, and $\left[{ }^{3} \mathrm{H}\right]$ arachidonic acid $(94.5 \mathrm{Ci} / \mathrm{mmol})$ were purchased from New England Nuclear (Boston, MA). Tissue culture medium was purchased from KC Biological Inc. (Lenexa, KS) or M. A. Bioproducts (Walkersville, MD). Fetal bovine serum was purchased from Hyclone Laboratories (Logan, UT). Collagenase was purchased from Cooper Biomedical (Malvern, PA). Antiserum to 6-ketoprostaglandin $F_{1 \alpha}$ was purchased from Advanced Magnetics, Inc. (Cambridge, MA). 1-steroyl-2-arachidonoyl phosphatidylcholine, 1,2 dioleoyl glycerol, phospatidylserine, and phospholipid standards were purchased from Avanti Polar Lipids (Alabaster, AL). Carbacyclin, $\mathrm{PGI}_{2}, \mathrm{PGF}_{2 \alpha}$, and $\mathrm{PGE}_{2}$ were purchased from BIOMOL Research Labs Inc. (Plymouth Meeting, PA). Monoclonal antibodies to prostaglandin $\mathrm{H}_{2}$ synthetase types I and II were a gift from Dr. Jacques Maclouf (INSERM, Paris, France). Monoclonal antibodies to the cytoplasmic PLA (designated $_{2}$ M3-1 and M12) were a gift from Dr. Ruth Kramer (Lilly Pharmaceuticals, Indianapolis, IN).

Cell culture. Bovine pulmonary artery endothelial cells were cultured as described (3) in medium 199 containing $25 \mathrm{mM}$ Hepes with $20 \%$ fetal bovine serum, $100 \mathrm{U} / \mathrm{ml}$ penicillin, and $100 \mu \mathrm{g} / \mathrm{ml}$ streptomycin. Human umbilical vein endothelial cells were cultured using a modification of the method of Jaffe et al. $(4,39)$. We have described the characteristics of both of these cells in culture $(3,39)$. All cells were used in primary culture except where indicated. Preconfluent cells were typically used $48 \mathrm{~h}$ after the initial plating when the cells diplayed an actively dividing morphology and were at a sparse density (covering $<25 \%$ of the cell area of the culture vessel). Cells progressed to confluence within 7-10 d after the initial plating and exhibited a tight, cobblestone morphology.

Measurement of $\mathrm{PGI}_{2}$ production by cells in culture. $\mathrm{PGI}_{2}$ production by cultured cells was quantitated by RIA of 6-ketoprostaglandin $F_{1 \alpha}$, the stable degradation product of $\mathrm{PGI}_{2}$, as described (40). The cells were washed twice with HBSS, and $2 \mathrm{ml}$ of HBSS containing an agonist was added to each plate. Control incubations were performed identically but without an agonist. For those experiments measuring prostacyclin formation in response to addition of exogenous arachidonic acid, cells were incubated in buffer (HBSS, $10 \mathrm{mM}$ Hepes, $1 \mathrm{mg} / \mathrm{ml} \mathrm{BSA}, \mathrm{pH} 7.4$ ) containing $30 \mu \mathrm{M}$ arachidonic acid. At the indicated time the stimulation buffer was removed for RIA. The sensitivity of the method was such that as little as 5-10 pg could be detected in an assay. The amount of 6-ketoprostaglandin $\mathrm{F}_{1 \alpha}$ standard giving 50\% inhibition of tracer binding was $\sim 50 \mathrm{pg}$. After removal of the supernatant, the cells were scraped into $1 \mathrm{ml}$ of water and the amount of protein present was determined by the method of Lowry (41). As an alternative measurement of cellular mass, cell lipids were extracted (42) and total lipid phosphate was measured (43). For those experiments examining the potential autocrine effects of $\mathrm{PGE}_{2}, \mathrm{PGF}_{2 \alpha}, \mathrm{PGI}_{2}$, and the stable $\mathrm{PGI}_{2}$ analogue, carbacyclin, the compounds were added to complete medium for $4 \mathrm{~h}$ before stimulation with calcium ionophore.

$\left[{ }^{3} \mathrm{H}\right]$ Arachidonic acid labeling and release from phospholipids. Endothelial cells were incubated for $2 \mathrm{~h}$ in medium (M199 $+1 \mathrm{mg} / \mathrm{ml}$ fatty acid-free bovine serum albumin) that contained $0.5 \mu \mathrm{Ci} / \mathrm{ml}$ of $\left[{ }^{3} \mathrm{H}\right]$ arachidonic acid. The labeling medium was removed and the monolayers were washed twice with HBSS. The monolayers were then incubated in M199 + 20\% fetal bovine serum for $24 \mathrm{~h}$ and then washed again (twice) with HBSS. The monolayers were incubated in stimulation buffer (HBSS, $10 \mathrm{mM}$ Hepes, $\mathrm{pH}$ 7.4) containing $10 \mu \mathrm{M}$ calcium ionophore A23187. Control incubations were performed identically but in the absence of the calcium ionophore. During this incubation, cells were examined by phase-contrast microscopy to confirm that cells did not detach from the culture vessel at the longer time points. If this occurred, those isolates were not used. The incubation was terminated by addition of acidified methanol and scraping the cells from the dish. In the experiments examining the distribution of $\left[{ }^{3} \mathrm{H}\right]$ arachidonic acid in various phospholipids after labeling, the labeling medium was removed and the monolayers were washed twice with HBSS. At the indicated time after labeling, the incubation was terminated by addition of acidified methanol to the stimulation buffer and scraping the cells from the dish. Cell lipids were extracted by the method of Bligh and Dyer (42). $20 \%$ of the organic phase was removed and the amount of radioactivity was determined by liquid scintillation spectroscopy to determine the total amount of label present in lipids. The remainder of the organic phase was dried under $\mathrm{N}_{2}$, resuspended in a small volume of chloroform/methanol (9:1), and the lipids were separated by TLC. For those experiments in which release of label from the individual phospholipids was measured, the plate was developed in solvent system $\mathrm{A}\left(\mathrm{CHCl}_{3} /\right.$ methanol/glacial acetic acid/water [100:30:35:3]). The percentage of total radioactivity in each lipid was determined by liquid scintillation spectroscopy, and the total amount of label in each phospholipid was calculated. The amount of $\left[{ }^{3} \mathrm{H}\right]$ arachidonic acid released from each phospholipid was then calculated as the difference between control and stimulated dishes. The percentage of release was calculated as the amount released from each phospholipid divided by the amount present in the unstimulated control. For experiments measuring the amount of label present in tri-, di-, and monoglycerides, free fatty acid, and phospholipids, the TLC plate was developed in solvent system $\mathrm{B}\left(\mathrm{CHCl}_{3} /\right.$ methanol/glacial acetic acid [98:2:1]), and the total amount of label present in each lipid was calculated in a manner identical to that used to determine the amount in the individual phospholipids (above). To examine the spectrum of arachidonic acid metabolites produced, preconfluent and confluent endothelial cells were labeled with $\left[{ }^{3} \mathrm{H}\right]$ arachidonic acid as above and stimulated with calcium ionophore $\left(10^{-5} \mathrm{M}\right.$ in HBSS, $10 \mathrm{mM}$ Hepes, $\mathrm{pH} 7.4,1$ $\mathrm{mg} / \mathrm{ml}$ of fatty acid-free BSA, $1 \mathrm{~h}$ ). The buffer was collected, acidified to $\mathrm{pH} 3.0$ with $1 \mathrm{~N}$ citric acid, and extracted three times with $5 \mathrm{vol}$ of ethyl acetate. The ethyl acetate was evaporated under $\mathrm{N}_{2}$; the lipids were separated by HPLC (1) and quantitated by liquid scintillation spectroscopy.

$\left[{ }^{3} \mathrm{H}\right]$ Arachidonic acid labeling and release from phospholipid subclasses. Endothelial cells were labeled with $\left[{ }^{3} \mathrm{H}\right]$ arachidonic acid, stimulated, and then extracted as described above. After $20 \%$ of the organic phase was used to measure the total amount of label present in the 
lipids, a portion of the remainder was separated by TLC in solvent system A to determine the percentage of total $\left[{ }^{3} \mathrm{H}\right]$ arachidonic acid in each phospholipid (phosphatidylethanolamine [PE], phosphatidylserine [PS], phosphatidylinositol [PI], and phosphatidylcholine [PC]). The remainder of the organic phase was separated by HPLC using the method of Patton (44). The eluents containing the individual phospholipids were collected and dried under nitrogen and used for determination of the amount of label in the subclasses of PC and PE. These fractions were derivatized to 1,2-diradyl-3-benzoylglycerols using the method of Blank et al. (45) and separated by TLC using the solvent system benzene/ hexane/diethyl ether (50:45:4). Each subclass was identified by comparison to authentic standards (diacyl, alkylacyl, and alk-1-enyl acyl). The amount of label present in each was measured by scintillation spectroscopy. The percentage of distribution of label in each subclass was calculated. The absolute amount of $\left[{ }^{3} \mathrm{H}\right]$ arachidonic acid present in each subclass was calculated as total disintegrations per minute in lipid $\times$ percentage in phospholipid $\times$ percentage in subclass. The percentage of release was then calculated as the difference in the amount of label present in a given subclass between stimulated and control cells. In control experiments, we found that recovery after the phospholipase $\mathrm{C}$ hydrolysis and benzoylation was $\sim 75 \%$, the same in each of the subclasses (diacyl, alkylacyl, and alk-1-enyl acyl).

Measurement of the relative amounts of $\left[{ }^{3} \mathrm{H}\right]$ arachidonic acid and $\left[{ }^{3} \mathrm{H}\right]$ docosatetraenoic acid. Endothelial cells were pulse labeled with $\left[{ }^{3} \mathrm{H}\right]$ arachidonic acid; at the indicated time after the addition of label, the endothelial cell lipids were extracted (42). In some experiments, labeled endothelial cells were exposed to buffer (HBSS $+10 \mathrm{mM}$ Hepes; $\mathrm{pH}$ 7.4) containing calcium ionophore (10 $\mu \mathrm{M} \mathrm{A23187)}$ for 60 $\mathrm{min}$. The organic phase of the extraction was dried under $\mathrm{N}_{2}$ and dissolved in $1.0 \mathrm{ml}$ of petroleum ether. $1 \mathrm{ml}$ of $\mathrm{BF}_{3} /$ methanol (Supelco) was added, and the mixture was heated to $100^{\circ} \mathrm{C}$ for $5 \mathrm{~min}$ and then cooled on ice. $1 \mathrm{ml}$ of water was added and the mixture was vortexed. The phases were separated by centrifugation $(1,000 \mathrm{~g} ; 2 \mathrm{~min})$. The upper phase was transferred to a conical tube and dried under nitrogen. The mixture of fatty acid methyl esters was dissolved in a small volume of acetonitrile and separated by reverse-phase HPLC using a $4.5 \mathrm{~mm}$ $\times 250 \mathrm{~mm} \mathrm{C18}$ ODS column eluted with acetonitrile and water (80:20). The percentage of acetonitrile was linearly increased to $90 \%$ over 30 min. The fractions containing $\left[{ }^{3} \mathrm{H}\right]$ arachidonic acid methyl ester and $\left[{ }^{3} \mathrm{H}\right]$ docosatetraenoic acid methyl ester were identified by comparison with authentic standards (Sigma Immunochemicals); the amount of radioactivity in each fraction was measured using liquid scintillation spectroscopy and the percentage of label in each fatty acid methyl ester was calculated. The retention times of arachidonic acid and docosatetraenoic acid methyl ester standards (16 and $24 \mathrm{~min}$, respectively) were identified by measurement of absorbance at $205 \mathrm{~nm}$.

Measurement of stimulated $\mathrm{PGI}_{2}$ production by endothelial cells in a wounded monolayer. Confluent monolayers of cultured bovine pulmonary artery endothelial cells were wounded by scraping with a sterile Teflon rake. The monolayer was raked in one direction, rotated 90 degrees, and raked again to give a cross-hatched pattern of injury. The medium was removed and the cells were washed twice with buffer (HBSS, $10 \mathrm{mM}$ Hepes; pH 7.4). Growth medium was then placed on the cells. Control monolayers were treated identically but were not wounded. Over the ensuing $72 \mathrm{~h}$, cells in the wounded cultures proliferated to fill in the denuded areas. At $0,4,8,18,28$, and $72 \mathrm{~h}$ after the wounding, the medium was removed, and the cells were washed with buffer and stimulated with calcium ionophore A23187 $\left(10^{-5} \mathrm{M}\right.$ in $2 \mathrm{ml}$ HBSS, $10 \mathrm{mM}$ Hepes; $\mathrm{pH} \mathrm{7.4)} \mathrm{for} 1 \mathrm{~h}$. At the end of the stimulation period, $1 \mathrm{ml}$ was removed and frozen for later measurement of 6ketoprostaglandin $F_{1 \alpha}$ by radioimmunoassay. The cells were scraped from the culture dish into the remaining $1 \mathrm{ml}$ with a Teflon scraper, removed from the dish, and frozen for later measurement of cell protein. The amount of 6-ketoprostaglandin $F_{1 \alpha}$ produced is expressed as nanograms of 6-ketoprostaglandin $F_{1 \alpha}$ per microgram of cell protein.

Measurement of arachidonic acid by gas liquid chromatography $(G L C)$. Preconfluent or confluent cells from the same isolate were scraped from culture dishes and the lipids were extracted by the method of Bligh and Dyer (42). $50 \mathrm{nmol}$ of di-C17 phosphatidylcholine was added as an internal standard. The organic phase was dried under nitrogen and redissolved in $1 \mathrm{ml}$ of petroleum ether and $1 \mathrm{ml}$ of borontrifluoride in methanol. This mixture was heated at $100^{\circ} \mathrm{C}$ for $5 \mathrm{~min}$ and cooled on ice. Water $(0.5 \mathrm{ml})$ was added and the tubes were shaken and centrifuged. The upper phase was removed and the lower phase was extracted with $1 \mathrm{ml}$ of hexane. These fractions were combined and dried under nitrogen. This was resuspended in $25 \mu \mathrm{l}$ of hexane and 1 $\mu \mathrm{l}$ was split-injected (100:1) into a gas chromatograph (model 3700; Varian Instrument Business, San Fernando, CA) fitted with a DB5 FSOT capillary column $(15 \mathrm{~m})$. The derivatized fatty acids were separated on a linear gradient from 140 to $200^{\circ} \mathrm{C}$ at $2^{\circ} \mathrm{C} / \mathrm{min}$ with $10 \mathrm{psi}$ helium. The derivatized fatty acids were identified by comparison of retention times to those of standards. The peak areas were integrated on an integrator (3390A; Hewlett-Packard Co., Palo Alto, CA) and mass was determined by comparison with the internal standard.

Cell cycle analysis. Cells were removed from culture dishes with trypsin; the cells were centrifuged $(500 \mathrm{~g}, 5 \mathrm{~min})$ and resuspended in calcium-free buffer (HBSS, no calcium, 1 mM EGTA). The cells were fixed by dropwise addition of ice-cold ethanol to the cell suspension with gentle vortexing, until the suspension was $70 \%$ ethanol, and then were stored overnight at $4^{\circ} \mathrm{C}$. The cells were then removed by centrifugation and the ethanol was decanted; the cells were resuspended in 0.5 $\mathrm{ml}$ phosphate-buffered saline. $15 \mu \mathrm{l}$ of RNAase (ribonuclease A, type II-A, $1 \mathrm{mg} / \mathrm{ml}$ in Tris-EDTA buffer) was added and the mixture was incubated for $30 \mathrm{~min}$ at $37^{\circ} \mathrm{C}$. Propidium iodide $(0.5 \mathrm{ml}$ of propidium iodide in PBS, $70 \mu \mathrm{g} / \mathrm{ml}$ ) was added to the suspension and the mixture was incubated for $30 \mathrm{~min}$ on ice. The percentage of cells in each cell cycle stage was measured as described (16).

Measurement of intracellular calcium. Changes in intracellular calcium changes in response to calcium ionophore stimulation were measured using Indo-1 spectrofluorimetry as described (36). Endothelial cells were grown on glass coverslips; sparse, preconfluent endothelial cells or confluent endothelial cells from the same isolate (that had been plated at higher density) were loaded with 1-[2-amino-5-(6-carboxyindol-2-yl)-phenoxy]-2-(2'-amino-5'-methylphenoxy)ethane- $N, N, N^{\prime}, N^{\prime}$ tetraacetic acid, pentaacetoxy-methylester (Indo-1 AM) $(10 \mu \mathrm{M} ; 1 \mathrm{~h}$ ), washed, and placed in the perfusion chamber of a custom-built spectrofluorimeter. The excitation wavelength was $360 \mathrm{~nm}$ and the detection wavelengths were 410 and $500 \mathrm{~nm}$. Fluorescence was recorded from single cells by the use of an iris in the emission pathway to control for any potential differences in signal that might arise as a result of differences in cell density. The cell was exposed to control buffer (HBSS $+10 \mathrm{mM}$ Hepes, $\mathrm{pH}$ 7.4) and a baseline was recorded. The cell was then exposed to buffer containing $10 \mu \mathrm{M}$ bromo-A23187, a nonfluorescent analogue of A23187. The ratio 410:500, expressed in arbitrary units, is proportional to intracellular calcium concentrations (36).

Measurement of PLA $A_{2}$ activity. PLA $\mathrm{A}_{2}$ activity was measured in homogenates of endothelial cells using a modification of the method of Clark et al. (33). The medium was removed from flasks of cultured endothelial cells at preconfluent and confluent points and the cells were washed with ice-cold buffer (HBSS; zero calcium; 2 mM EGTA). The cells were then scraped from the flask into the same buffer, recovered by centrifugation $(500 \mathrm{~g} ; 10 \mathrm{~min})$ and frozen at $-70^{\circ} \mathrm{C}$ until assayed. $500 \mu$ l of lysis buffer ( $140 \mathrm{mM} \mathrm{NaCl}, 5 \mathrm{mM} \mathrm{KCl}, 2 \mathrm{mM}$ EGTA, 10 $\mathrm{mM}$ Hepes, pH 7.4, $1 \mathrm{mM}$ PMSF, $100 \mu \mathrm{M}$ leupeptin, $1 \mathrm{mM}$ DTT, and $100 \mu \mathrm{g} / \mathrm{ml}$ aprotinin) was added to the frozen cell pellet. The cells were disrupted by nitrogen cavitation ( $750 \mathrm{psi} ; 20 \mathrm{~min})$ and the cell lysate was centrifuged at $100,000 \mathrm{~g}$ for $45 \mathrm{~min}$; the supernatant (cytosolic) was removed for subsequent assay. The assay (total volume $=500 \mu \mathrm{l}$ ) contained $150 \mathrm{mM} \mathrm{NaCl}, 2 \mathrm{mM} \mathrm{CaCl}, 50 \mathrm{mM}$ Hepes, pH 7.4, $2 \mathrm{mM}$ DTT, $2 \mathrm{mg} / \mathrm{ml}$ fatty acid-free BSA, $2 \mu \mathrm{M}$ 1,2-dioleoyl glycerol, and 4 $\mu \mathrm{M}$ 1-stearoyl-2-[ $\left.{ }^{3} \mathrm{H}\right]$ arachidonoyl phosphatidylcholine $(400,000 \mathrm{dpm}$ per assay). The substrate was prepared by drying the appropriate amounts of diglycerol and labeled and unlabeled 1-stearoyl-2-arachidonoyl phosphatidylcholine under nitrogen. These lipids were resuspended in assay buffer and briefly sonicated in a bath sonicator. The incubation was initiated by the addition of the cell lysate (containing 5-10 $\mu \mathrm{g}$ cell 
protein) and maintained in a water bath at $37^{\circ} \mathrm{C}$. The incubation was terminated by the addition of $1 \mathrm{ml}$ of chloroform/acidified methanol ( $1 \%$ glacial acetic acid in methanol [vol/vol]) (1:2). The lipids were extracted from this mixture by the method of Bligh and Dyer (42). The unreacted substrate and the product were separated using thin layer chromatography chloroform/methanol/glacial acetic acid (90:10:10). The fractions containing $\left[{ }^{3} \mathrm{H}\right]$ arachidonic acid and the substrate were scraped from the plate and the amount of radioactivity in each was measured using liquid scintillation spectroscopy. The assay was linear over time (0-30 min), the amount of cell protein $(5-10 \mu \mathrm{g})$, and the amount of substrate hydrolyzed $(<5 \%)$. For some experiments the cell homogenate was treated with a monoclonal antibody that specifically neutralizes the cytoplasmic PLA ${ }_{2}$ activity (M12) (46) or a control antibody that binds to, but does not neutralize, the cytoplasmic PLA (M3- $^{2}$ 1) (46). In those experiments, the cell lysate was incubated with the antibody $(1 \mathrm{mg} / \mathrm{ml})$ or control buffer for $60 \mathrm{~min}$ on ice. This mixture

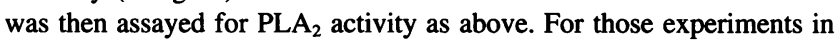
which the cell lysate was treated with phosphatase, the cells were placed in lysis buffer that did not contain PMSF and contained $20 \mathrm{mM}$ BisTris ( $\mathrm{pH} \mathrm{6.5)} \mathrm{in} \mathrm{place} \mathrm{of} \mathrm{Hepes.} \mathrm{The} \mathrm{cell} \mathrm{lysate} \mathrm{was} \mathrm{incubated} \mathrm{with} 10$ $\mathrm{U}$ of potato acid phosphatase (type VII) for $60 \mathrm{~min}$ at $30^{\circ} \mathrm{C}$. Control incubations contained phosphatase inhibitors $(50 \mathrm{mM} \mathrm{NaF}$ and $0.2 \mathrm{mM}$ $\mathrm{Na}_{3} \mathrm{VO}_{4}$ ) or equal amounts of the vehicle for the potato acid phosphatase [1.8 $\mathrm{M}\left(\mathrm{NH}_{4}\right)_{2} \mathrm{SO}_{4}, 10 \mathrm{mM} \mathrm{MgCl} 2, \mathrm{pH}$ 5.5]. The dephosphorylation reaction was terminated by the addition of phosphatase inhibitors (50 $\mathrm{mM} \mathrm{NaF}$ and $0.2 \mathrm{mM} \mathrm{Na}_{3} \mathrm{VO}_{4}$ [final concentrations]) and the amount of $\mathrm{PLA}_{2}$ activity was quantitated as described above.

Measurement of PI-specific phospholipase C (PI-PLC) activity. PIPLC activity was measured using the method of Hoffman et al. (47). Reaction mixtures contained $250 \mu \mathrm{M}$ PI, 60,000-100,000 dpm L- $\alpha$ [myo-inositol-2- ${ }^{3} \mathrm{H}(N)$ ]PI $(220 \mathrm{dpm} / \mathrm{pmol}), 1 \mathrm{mg} / \mathrm{ml}$ of sodium deoxylcholate, $1 \mathrm{mM} \mathrm{CaCl}, 0.5 \mathrm{mg} / \mathrm{ml}$ of bovine serum albumin, $100 \mathrm{mM}$ $\mathrm{NaCl}, 50 \mathrm{mM}$ Hepes, $\mathrm{pH} \mathrm{7.0,} \mathrm{and} \mathrm{5-25} \mu \mathrm{g}$ of cell protein in a total volume of $200 \mu \mathrm{l}$. The reaction was begun by the addition of the endothelial cell homogenate $(20 \mu \mathrm{l})$ and was allowed to proceed at $37^{\circ} \mathrm{C}$ for $10 \mathrm{~min}$. The reaction was terminated by the addition of $1 \mathrm{ml}$ of $\mathrm{CHCl}_{3} /$ methanol/concentrated $\mathrm{HCl}(100: 100: 6)$ followed by $0.3 \mathrm{ml}$ of $1 \mathrm{~N} \mathrm{HCl}$ containing $5 \mathrm{mM}$ EGTA. The mixture was vortexed and centrifuged $(500 \mathrm{~g}, 5 \mathrm{~min})$. A portion of the aqueous phase $(400 \mu \mathrm{l})$ was removed for scintillation counting. The assay was linear with respect to time and the amount of cell homogenate added with $<5 \%$ hydrolysis of the substrate. Purified PI-PLC from ram seminal vesicles (47) was used as a positive control.

Immunoblotting and reverse transcriptase polymerase chain reaction. Preconfluent, human umbilical vein endothelial cells were harvested $2 \mathrm{~d}$ after initial plating. A fraction was removed for measurement of protein content and the remainder was placed in SDS-PAGE sample buffer and frozen at $-70^{\circ} \mathrm{C}$. Confluent cells were harvested in identical fashion $5 \mathrm{~d}$ later. Cell proteins were separated by SDS-PAGE as described (48) and were electrophoretically transferred to a polyvinyldifluoride membrane (Immobilon; Millipore Corp., Bedford, MA). Immunoblotting was performed as described (48) using, in turn, monoclonal antibodies that specifically recognize prostaglandin $\mathrm{H}_{2}$ synthetase type I, prostaglandin $\mathrm{H}_{2}$ synthetase type II, and the cytoplasmic PLA The immunoblots were developed using an enhanced chemiluminescent assay (Amersham Corp., Arlington Heights, IL). For estimation of the relative amounts of mRNA coding for the prostaglandin $\mathrm{H}_{2}$ synthetases I and II and the cytoplasmic PLA 2 , mRNA was extracted from preconfluent and confluent cells from the same isolate using guanidinium thiocyanate (49) and cDNA was prepared as described using murine leukemia virus reverse transcriptase (49). Polymerase chain reaction amplification of cDNA was performed with primers recognizing unique sequences of prostaglandin $\mathrm{H}_{2}$ synthetase I (50-52), prostaglandin $\mathrm{H}_{2}$ synthetase II (13), or the cytoplasmic PLA 2 (34). Primers specific for glyceraldehyde-3-phosphate dehydrogenase (53) were used as a control. The amplified cDNAs were separated on a $1.2 \%$ agarose gel and stained with ethidium bromide. Estimates of the relative amounts of message were made by comparing the intensity of the bands specific for each product, using glyceraldehyde-3-phosphate dehydrogenase as a denominator.

\section{Results}

Stimulated production of prostacyclin decreases as endothelial cells progress to confluence in culture. Some investigators have reported that stimulated production of prostacyclin by endothelial cells changes with increasing time in culture or with repeated passage of the cells although the pattern of change is variable from study to study $(1,14-16)$. To clarify this, we first examined the stimulated production of prostacyclin $\left(\mathrm{PGI}_{2}\right)$, the major arachidonic acid metabolite, by endothelial cells as they progressed from an actively dividing, preconfluent state to a contact-inhibited monolayer. We stimulated bovine endothelial cells with calcium ionophore and measured the amount of 6-keto $\mathrm{PGF}_{1 \alpha}$, the stable hydrolysis product of $\mathrm{PGI}_{2}$. Actively dividing, sparse cells produced $13.2 \pm 1.7 \mathrm{ng}$ of $\mathrm{PGI}_{2} / \mathrm{nmol}$ of cellular phospholipid (mean $\pm \mathrm{SD} ; n=6$ ). In contrast, monolayers that were confluent produced only $6.1 \pm 0.7 \mathrm{ng} \mathrm{PGI} / \mathrm{nmol}$ of cellular phospholipid ( $n=6 ; P>0.001)$. We asked whether this change was limited to bovine cells from pulmonary artery or was a more general one. To assess this, we examined human endothelial cells derived from umbilical vein under the same conditions and found that they demonstrated the same phenomenon: $\mathrm{PGI}_{2}$ formation per cell was twice as high in preconfluent cells as in confluent cells. To exclude different kinetics of release under the two growth conditions as an explanation for this effect, we performed a time course and found that release was $>95 \%$ complete within $1 \mathrm{~h}$ for cells at either growth state (not shown). The diminished release at confluence was apparent regardless of what measure of cell mass was used (cellular protein or phospholipid, or cell number). These experiments were performed with calcium ionophore A23187 to avoid any possible differences due to quantitative or qualitative differences in receptors for other agonists that mediate arachidonic acid release.

The observed differences in prostacyclin formation could have arisen from differences in the initial release of arachidonic acid from its phospholipid storage site or from differences in the subsequent metabolism of the arachidonic acid (e.g., differences in the activity of prostaglandin $\mathrm{H}_{2}$ synthetase or prostacyclin synthetase). To test the latter hypothesis, we measured the amount of prostacyclin produced by preconfluent and confluent cells when they were supplied with exogenous arachidonic acid. Prostacyclin formation (normalized to the amount of cell protein) was no different in the preconfluent cells compared with the confluent cells when exogenous arachidonic acid was provided (Fig. 1). As before, controls exposed to a calcium ionophore showed a marked decrease in the amount of prostacyclin formed in confluent compared with preconfluent cells. In addition, we quantitated the amounts of prostaglandin $\mathrm{H}_{2}$ synthetase (both prostaglandin $\mathrm{H}_{2}$ synthetase and the inducible prostaglandin $\mathrm{H}_{2}$ synthetase [13]) by Western blotting and found that the amounts in preconfluent cells were no greater than those in confluent cells (not shown). Similarly, PCR amplification of mRNA for prostaglandin $\mathrm{H}_{2}$ synthetase and the inducible prostaglandin $\mathrm{H}_{2}$ synthetase (13) showed no difference in the amount of message for each in cells at the different growth states (not shown). Consistent with these findings, there was no difference in the spectrum of eicosanoids produced by the cells at the two different growth states. 6-keto $\mathrm{PGF}_{1 \alpha}$, the stable 


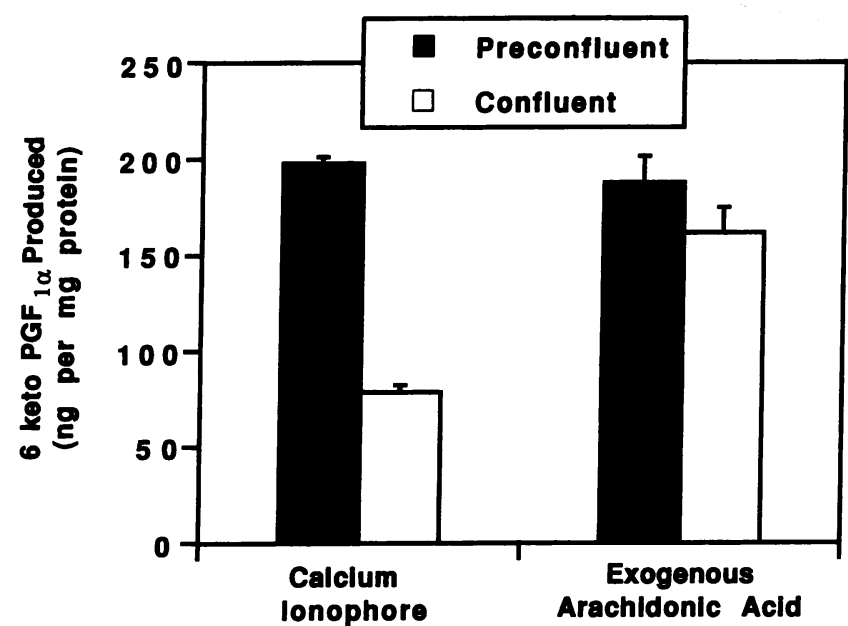

Figure 1. Formation of $\mathrm{PGI}_{2}$ from exogenous arachidonic acid is not affected by progression to confluence. Preconfluent human umbilical vein endothelial cells ( $3 \mathrm{~d}$ after plating) were incubated in buffer (HBSS; $10 \mathrm{mM}$ Hepes, $1 \mathrm{mg} / \mathrm{ml}$ BSA; $\mathrm{pH} 7.4$ ) containing arachidonic acid (30 $\mu \mathrm{M})$ or calcium ionophore A23187 $(10 \mu \mathrm{M})$ for $1 \mathrm{~h}$ at $25^{\circ} \mathrm{C}$. The buffer was removed and the amount of 6-keto $\mathrm{PGF}_{1 \alpha}$ was measured by radioimmunoassay. The cells were then scraped into HBSS and the amount of cell protein was measured. $3 \mathrm{~d}$ later, confluent cells from the same isolate were treated in identical fashion. Each group includes measurements made in four separate dishes. There was no significant difference in the amounts of 6-keto $\mathrm{PGF}_{1 \alpha}$ produced in response to exposure to arachidonic acid between confluent and preconfluent cells.

metabolite of $\mathrm{PGI}_{2}$, was the predominant product with lesser amounts of $\mathrm{PGF}_{2 \alpha}, \mathrm{PGE}_{2}$, and products that comigrated with hydroxyeicosatetraenoic acids (data not shown). These data demonstrate that the step responsible for the growth-dependent alteration in prostacyclin formation was proximal to prostaglandin $\mathrm{H}_{2}$ synthetase.

We next tested the hypothesis that the initial release of arachidonic acid decreased as cells progressed to confluence in culture, since this step, thought to be catalyzed by a PLA $A_{2}$, is conditional for prostaglandin production. To test this we labeled endothelial cells with $\left[{ }^{3} \mathrm{H}\right]$ arachidonic acid, stimulated them with calcium ionophore, and determined the percentage of $\left[{ }^{3} \mathrm{H}\right]-$ arachidonic acid released from phospholipids. We carried out multiple experiments using cells from independent isolations, and in each experiment we compared preconfluent and confluent cells from the same isolate. Preconfluent cells released $30.1 \pm 5.4 \%$ of the $\left[{ }^{3} \mathrm{H}\right]$ arachidonic acid present in phospholipids, while the confluent cells released only $6.3 \pm 5.2 \%$ (mean \pm SD from 10 experiments). We again examined the possibility that the observed difference was due to altered kinetics of release in the two populations. However, a time course of stimulated arachidonic acid release demonstrated that release was complete within $1 \mathrm{~h}$ in both the preconfluent and confluent cells (Fig. 2). The decline in release of $\left[{ }^{3} \mathrm{H}\right]$ arachidonic acid as the cells progressed to confluence occurred in each phospholipid (Table I) and in the subclasses of PE and PC (Table II).

The experiments that measured the release of $\left[{ }^{3} \mathrm{H}\right]-$ arachidonic acid were performed with cells that had been labeled $24 \mathrm{~h}$ before stimulation to allow steady state labeling of the cellular arachidonic acid pool. These tracer radiolabeling studies gave similar results to the experiments in which prostacyclin production from unlabeled precursor was measured by

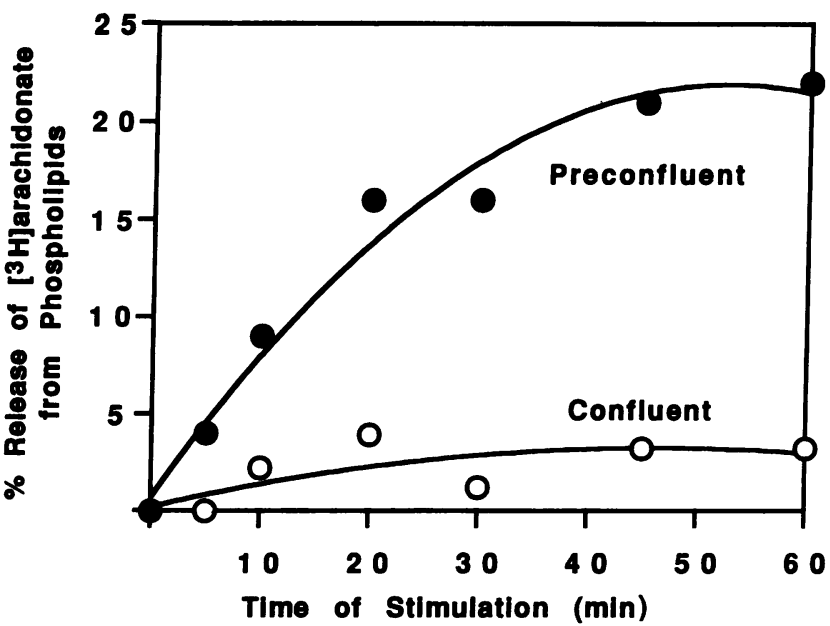

Figure 2. Time course of stimulated $\left[{ }^{3} \mathrm{H}\right]$ arachidonic acid release in preconfluent compared with confluent endothelial cells. Preconfluent endothelial cells from bovine pulmonary artery were labeled with $\left[{ }^{3} \mathrm{H}\right]-$ arachidonic acid $(0.5 \mu \mathrm{Ci} / \mathrm{ml}$ in $\mathrm{M} 199+1 \mathrm{mg} / \mathrm{ml}$ of fatty acid-free bovine serum albumin; $2 \mathrm{~h}$ ). The labeling medium was removed, and the monolayer was washed twice with HBSS and then incubated in standard growth medium for $24 \mathrm{~h}$. The medium was then removed and replaced with buffer (HBSS/Hepes) or buffer containing calcium ionophore. At the indicated time, the incubation was terminated by the addition of acidified methanol. The lipids were extracted, the amount of $\left[{ }^{3} \mathrm{H}\right]$ arachidonic acid in cell phospholipids was measured, and the percentage of release of $\left[{ }^{3} \mathrm{H}\right]$ arachidonic acid was calculated as described in Methods (closed circles). Cells from the same isolate that had progressed to confluence were labeled and stimulated in identical fashion (open circles). Each point represents the mean of determinations made in three separate $60-\mathrm{mm}$ dishes (the mean of three control dishes compared with three stimulated dishes). The mean incorporation of $\left[{ }^{3} \mathrm{H}\right]$ arachidonic acid into preconfluent cell lipids (control) was 48,000 $\mathrm{dpm} / \mathrm{dish}$, and the mean percentages of total label in each phospholipid were: PC $36.2 \%$, PI/PS $16.5 \%$, and PE $38.2 \%$. The mean incorporation of $\left[{ }^{3} \mathrm{H}\right]$ arachidonic acid into confluent cell lipids (control) was 109,400 dpm/dish, and the mean percentages of total label in each phospholipid were: PC $35.2 \%$, PI/PS $15.7 \%$, and PE $37.1 \%$. (PI and PS were not completely resolved in this chromatographic separation.)

radioimmunoassay, suggesting that the results were reflective of the metabolism of endogenous arachidonic acid. However, it is possible that labeling of arachidonic acid pools was heterogeneous. Therefore, we performed control experiments to exclude the possibility that the result of the tracer studies was an artifact resulting from nonuniform labeling. First, we found that $\left[{ }^{3} \mathrm{H}\right]$ arachidonic acid redistributed between phospholipids and phospholipid subclasses in the 24-h period after the pulse labeling, and the pattern of that redistribution was the same in preconfluent and confluent cells (Fig. 3, $a-d$ ). In both cases, there was a net redistribution of $\left[{ }^{3} \mathrm{H}\right]$ arachidonic acid from PC (and, to a lesser extent, PI) to PE (Fig. 3, $a$ and $b$ ). Similarly, there was a net loss of $\left[{ }^{3} \mathrm{H}\right]$ arachidonic acid from triglyceride over the same period (Fig. 3, c and $d$ ). After the pulse, $\left[{ }^{3} \mathrm{H}\right]-$ arachidonic acid was predominantly found in the diacyl subclass of PC and of PE; in addition, similar to previous observations in confluent monolayers $(54,55)$, there was a net shift of label into the plasmalogen subclass of PE in the $24 \mathrm{~h}$ after labeling in both preconfluent and confluent cells (data not shown). Consequently, although redistribution of $\left[{ }^{3} \mathrm{H}\right]$ arachidonic acid occurred after the pulse labeling, it was largely completed in the 
Table I. Distribution of $\left[{ }^{3} \mathrm{H}\right]$ Arachidonic Acid in Endothelial Cell Phospholipids and Pattern of Release in Response to Stimulation

\begin{tabular}{lcrcc}
\hline & \multicolumn{5}{c}{ Percentage of $\left[{ }^{3} \mathrm{H}\right]$ arachidonic acid } \\
\cline { 2 - 5 } & PC & PI & PS & PE \\
\hline Preconfluent & & & & \\
$\quad$ Control & 35.5 & 11.2 & 3.2 & 40.2 \\
$\quad$ Stimulated & 24.3 & 9.2 & 3.0 & 28.6 \\
Confluent & & & & \\
$\quad$ Control & 35.2 & 14.5 & 3.7 & 33.7 \\
$\quad$ Stimulated & 29.3 & 14.5 & 3.5 & 28.0 \\
\hline
\end{tabular}

\begin{tabular}{lccccc} 
& \multicolumn{5}{c}{ Percentage of $\left[{ }^{3} \mathrm{H}\right]$ arachidonic acid released } \\
\cline { 2 - 6 } & PC & PI & PS & PE & Total \\
\hline Preconfluent & 42.1 & 30.5 & 20.7 & 39.8 & 38.9 \\
Confluent & 15.7 & $(3.4)$ & 4.2 & 15.9 & 12.2
\end{tabular}

Preconfluent ( $2 \mathrm{~d}$ after initial plating) or confluent bovine pulmonary artery endothelial cells from the same isolate ( $8 \mathrm{~d}$ after plating) were pulse labeled with [ $\left.{ }^{3} \mathrm{H}\right]$ arachidonic acid $(0.5 \mu \mathrm{Ci} / \mathrm{ml} \mathrm{M} 199+1 \mathrm{mg} / \mathrm{ml}$ fatty acid-free BSA; $2 \mathrm{~h}$ ) followed by incubation in unlabeled growth medium for $24 \mathrm{~h}$. The medium was then removed and replaced with control buffer or buffer containing $10 \mu \mathrm{M} \mathrm{A} 23187$ for $1 \mathrm{~h}$. The percentage of distribution of $\left[{ }^{3} \mathrm{H}\right]$ arachidonic acid present in each phospholipid was determined after extraction of cell lipids and separation of lipids by thin layer chromatography (see Methods). The distribution of label in each phospholipid (PC, PI, PS, and PE) as a percentage of total cell lipids is shown. The percentage of $\left[{ }^{3} \mathrm{H}\right]$ arachidonic acid released from each phospholipid and from all phospholipids (Total) was then calculated. In confluent cells, the amount of label in PI in stimulated cells was greater than in unstimulated cells; hence the percent release is a negative value.

24-h chase period before stimulation; moreover, this redistribution was the same in both preconfluent and confluent cells. Second, as another test of the possibility that the protocol was resulting in labeling of different pools, we labeled cells at a preconfluent point and allowed them to progress to confluence before being stimulated. Parallel wells from the same isolate were cultured to confluence and then labeled by the usual protocol. Both labeling conditions demonstrated the same decreased release in the confluent cells (data not shown). Finally, the decreased release at confluence was observed in each phospholipid and each subclass of PE and PC (Tables I and II). Consequently, we conclude that the changes in $\left[{ }^{3} \mathrm{H}\right]$ arachidonic acid release at the different growth states were not due to differences in which phospholipids or their subclasses were labeled, nor was the decreased release in confluent cells a result of sequestration of $\left[{ }^{3} \mathrm{H}\right]$ arachidonic acid into an inert pool.

Another possibility was that the alteration in release of $\left[{ }^{3} \mathrm{H}\right]-$ arachidonic acid at different growth states might have arisen due to differences in metabolism of the label. Others have shown that endothelial cells elongate arachidonic acid (20:4) to docosatetraenoic acid (22:4) (56). It was possible that the tracer $\left[{ }^{3} \mathrm{H}\right]$ arachidonic acid was elongated more rapidly by the confluent cells, and the product was not as suitable a substrate for release as arachidonic acid. This was excluded when we measured the amount of the tracer $\left[{ }^{3} \mathrm{H}\right]$ arachidonic acid converted
Table II. Release of $\left[{ }^{3} \mathrm{H}\right]$ Arachidonic Acid from Subclasses of PE and PC

\begin{tabular}{lccc}
\hline & \multicolumn{3}{c}{ Percent released } \\
\cline { 2 - 4 } & Diacyl & Alkylacyl & Plasmalogen \\
\hline PE & & & \\
$\quad$ Preconfluent & 40.9 & 35.9 & 38.7 \\
$\quad$ Confluent & 15.0 & 2.1 & 17.2 \\
PC & & & $*$ \\
$\quad$ Preconfluent & 42.0 & 41.9 & $*$ \\
Confluent & 15.0 & 17.9 & $*$ \\
\hline
\end{tabular}

A portion (50\%) of labeled cell lipids from the experiment shown in Table I was separated by HPLC and the fractions containing PE and $\mathrm{PC}$ were collected. The percentage of distribution of $\left[{ }^{3} \mathrm{H}\right]$ arachidonic acid present in each subclass of $\mathrm{PE}$ and $\mathrm{PC}$ and the percentage of release of $\left[{ }^{3} \mathrm{H}\right]$ arachidonic acid from stimulated cells compared with control was determined as described in Methods, after derivatization to 1-radyl$2-\left[{ }^{3} \mathrm{H}\right]$ arachidonoyl-glycerobenzoates. Results shown are from a single experiment. In two other experiments, using cells from separate isolates, recovery of the derivatized glycerobenzoates from the preconfluent cells was inadequate for measurement of the percentage of release of label from the minor subclasses; the release from the diacyl classes of PC and PE and the plasmalogen class of PE was qualitatively the same as in the experiment shown. * The plasmalogen class of PC comprised $<3 \%$ of the total label in PC and the amount of radioactivity was not sufficiently above background levels to provide a reliable calculation of percentage of release.

to $\left[{ }^{3} \mathrm{H}\right]$ docosatetraenoate and found it to be the same in preconfluent and confluent cells (not shown).

We also considered the possibility that confluent cells are relatively depleted of arachidonic acid. To assess this, and to evaluate the correlation of radiolabeled arachidonic acid with endogenous, we measured the fatty acid composition of the cells at different growth states with GLC. We found that their arachidonic acid content increased from 11.3 to 17.1 mole percent during the progression from a preconfluent to a confluent state. This probably was due to incorporation of arachidonic acid from the serum in the medium. We also used this method to examine arachidonic acid release. Preconfluent or confluent cultures were stimulated with the calcium ionophore, and then their content of arachidonic acid was measured after release. The mole percent of arachidonic acid fell from 11.3 to 8.4 in preconfluent cells, a decrease of $25.2 \pm 1.5 \%$ (mean \pm SD of determinations in cells from four isolates). In contrast, the mole percent of arachidonic acid in confluent cells only decreased from 17.1 to 16.0 , a decrease of $6.7 \pm 4.0 \%$. In three experiments examining release of both $\left[{ }^{3} \mathrm{H}\right]$ arachidonic acid and unlabeled arachidonic acid, the percentage of change in response to stimulation was similar by radiolabel or GLC (Table III).

The alteration in arachidonic acid release is dependent upon the proliferative state of the cell. Our initial studies of the changes in the stimulated release of $\left[{ }^{3} \mathrm{H}\right]$ arachidonic acid and production of $\mathrm{PGI}_{2}$ defined the different growth states of the cells by their morphology under phase-contrast microscopy. We repeated similar experiments in which we used a more quantitative analysis of their growth state. We determined the percentage of cells in $G_{2}+M$ phase of the cell cycle as the cells progressed to confluence, and in the same experiments, we measured the release of $\left[{ }^{3} \mathrm{H}\right]$ arachidonic acid at different times (Fig. 


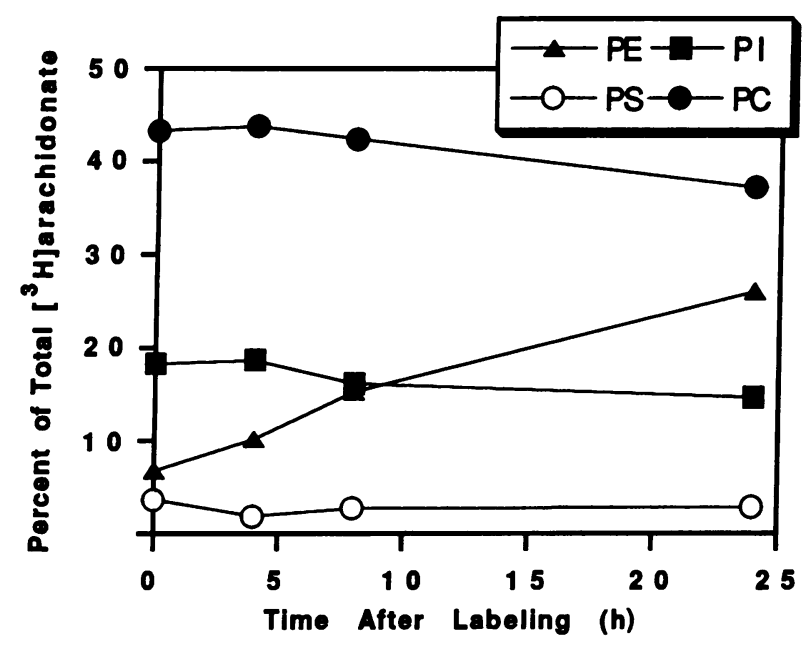

$\mathbf{c}$

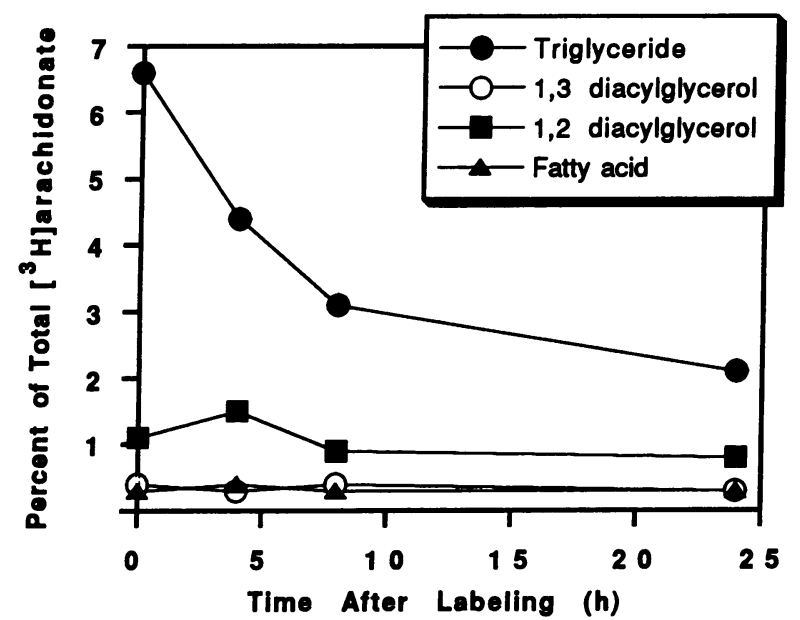

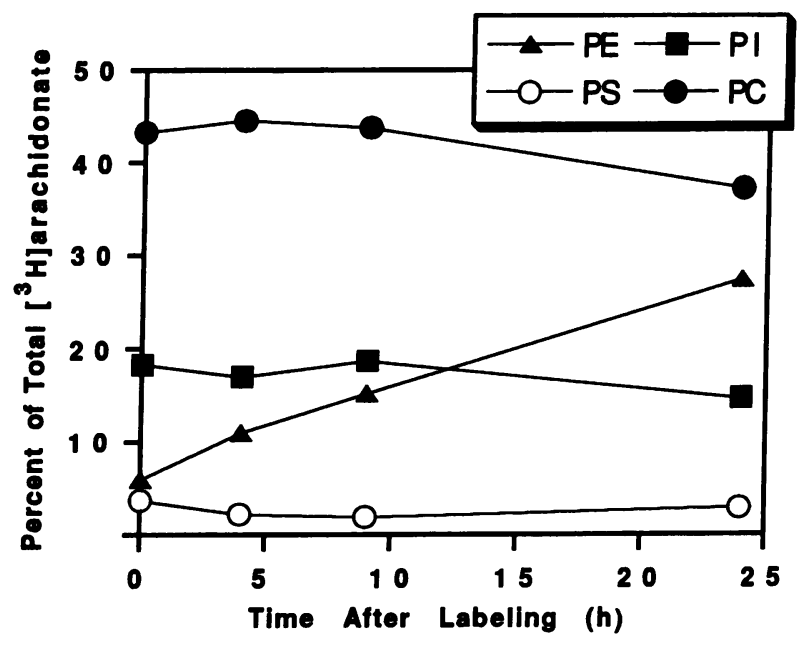

d

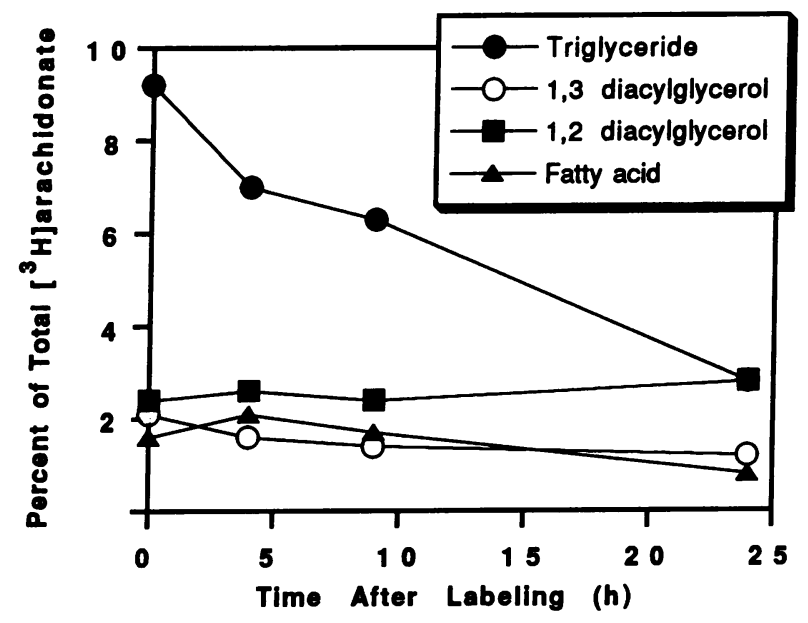

Figure 3. Distribution of $\left[{ }^{3} \mathrm{H}\right]$ arachidonic acid among lipids after a pulse labeling in cells at different growth states. $(a$ and $c$ ) Preconfluent bovine endothelial cells ( $48 \mathrm{~h}$ after plating) were pulse labeled with $\left[{ }^{3} \mathrm{H}\right]$ arachidonic acid for $2 \mathrm{~h}$ as described in Methods. At the indicated time after the pulse labeling, the lipids were extracted, and the amount of $\left[{ }^{3} \mathrm{H}\right]$ arachidonic acid present as free arachidonic acid, esterified to phospholipid and diand triglyceride, was determined after separation by thin layer chromatography. Each point represents the mean of triplicate determinations. The mean incorporation of $\left[{ }^{3} \mathrm{H}\right]$ arachidonic acid into total cell lipids was $74,500 \mathrm{dpm} / \mathrm{flask}$. ( $b$ and $\left.d\right)$ The distribution of $\left[{ }^{3} \mathrm{H}\right]$ arachidonic acid after pulse labeling of confluent bovine endothelial cells was measured in identical fashion to $a$ and $c$. The mean incorporation of $\left[{ }^{3} \mathrm{H}\right]$ arachidonic acid into total cell lipids was $181,300 \mathrm{dpm} /$ flask.

4). These experiments confirmed that stimulated release of $\left[{ }^{3} \mathrm{H}\right]-$ arachidonic acid was greater in actively dividing (preconfluent) cells compared with quiescent cultures (confluent).

Endothelial and other cells may express different phenotypes with time in culture but without clear relationship to their proliferative state. We tested the hypothesis that the decreased arachidonic acid release was related to time in culture rather than the growth state by measuring the release of $\left[{ }^{3} \mathrm{H}\right]-$ arachidonic acid from endothelial cells that had been passed to two different densities. Confluent, primary cultures of endothelial cells were harvested and subcultured in a 1:3 split (onethird density). Control cells were treated identically except they were subcultured in a ratio of 1:1 (harvested and replated at the same density). Stimulated release of $\left[{ }^{3} \mathrm{H}\right]$ arachidonic acid from these cells showed that the cells passed to a lower density released $26.4 \%$ of label (Table IV). In contrast, cells passed to high density released only $12.1 \%$ of label (Table IV) and the decreased release at higher cell density was seen in each phospholipid (Table IV), similar to results in cells progressing to confluence in primary culture. From these results we can reject the hypothesis that the decreasing release was simply a consequence of increasing time in culture, as the time in culture was identical.

In subsequent studies we asked whether this change (i.e., decreased release) was reversible. To do so, we measured the stimulated production of $\mathrm{PGI}_{2}$ by endothelial cells that were converted from the quiescent, confluent monolayer to an actively proliferating state. Confluent monolayers were wounded in a cross-hatch pattern with a Teflon rake; the cells proliferated to cover the denuded areas. During this period, stimulated production of $\mathrm{PGI}_{2}$ was measured and compared with unwounded controls. The stimulated production of $\mathrm{PGI}_{2}$ (per cell mass) 
Table III. Stimulated Alterations in Fatty Acid Composition of Endothelial Cell Lipids Compared with $\left[^{3} \mathrm{H}\right]$ Arachidonic Acid Release

\begin{tabular}{cccccc}
\hline & \multicolumn{2}{c}{ Preconfluent } & & \multicolumn{2}{c}{ Confluent } \\
\cline { 2 - 3 } \cline { 5 - 6 } Experiment & $\begin{array}{c}\text { Loss of } \\
{\left[{ }^{3} \mathrm{H}\right] \mathrm{AA}}\end{array}$ & $\begin{array}{c}\text { Change } \\
\text { in 20:4 }\end{array}$ & & $\begin{array}{l}\text { Loss of } \\
{\left[{ }^{3} \mathrm{H}\right] \mathrm{AA}}\end{array}$ & $\begin{array}{r}\text { Change } \\
\text { in 20:4 }\end{array}$ \\
\hline 1 & 34.5 & 23.7 & & 0 & 10.7 \\
2 & 29.6 & 27.7 & & 12.9 & 10.9 \\
3 & 19.4 & 24.7 & & 11.2 & 3.4 \\
\hline
\end{tabular}

Cultured bovine pulmonary artery endothelial cells at a preconfluent growth state were labeled with $\left[{ }^{3} \mathrm{H}\right]$ arachidonic acid and stimulated with calcium ionophore $\left(10^{-5} \mathrm{M}\right)$ or buffer alone for $1 \mathrm{~h}$. Confluent cells were treated in identical fashion. The endothelial cell lipids were extracted and split into two fractions. One fraction was used to measure percentage of release from phospholipids as described in Methods. The other fraction was analyzed for fatty acid composition: after the addition of a di-C17 internal standard, the fatty acids were derivatized to methyl esters, separated, and were quantitated by gas chromatography, and the mole percent of each fatty acid was calculated. Shown are the percentages of release of $\left[{ }^{3} \mathrm{H}\right]$ arachidonic acid from phospholipids (Loss of $\left.\left[{ }^{3} \mathrm{H}\right] \mathrm{AA}\right)$ and the percentage of change in mole percent of arachidonic acid (Change in 20:4). Shown are results from three experiments using cells from separate isolates.

increased in the wounded cultures with a maximal increase observed at 8-12 h after wounding (Fig. 5). These data strongly suggest that the increased release of arachidonic acid (and synthesis of $\mathrm{PGI}_{2}$ ) is related to the proliferative state of the cell. Further, this and other experiments in which we measured release of $\left[{ }^{3} \mathrm{H}\right]$ arachidonic acid (not shown) demonstrate that the arachidonic acid release phenotype is reversible; although the usual growth pattern would progress from a high to low release phenotype, the converse is also possible.

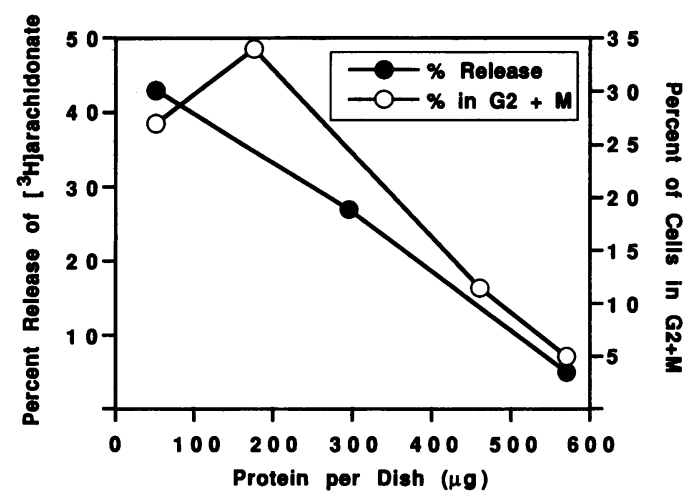

Figure 4. The percentage of release of $\left[{ }^{3} \mathrm{H}\right]$ arachidonic acid from cell phospholipids as related to the cell cycle stage. The percentage of release of $\left[{ }^{3} \mathrm{H}\right]$ arachidonic acid from cell phospholipids was measured as in Fig. 2. Cells from the same isolate, in parallel culture, were harvested and fixed for cell cycle analysis as described in Methods. Results shown are from a single experiment. The mean incorporations of $\left[{ }^{3} \mathrm{H}\right]$ arachidonic acid into total cell lipids (preconfluent, midconfluent, and confluent) were $62,500,98,300$, and $124,900 \mathrm{dpm}$, respectively (per 60-mm dish). The percentages of total label in phospholipids (PC + Pl + PS + PE) were $88.9,90.2$, and $89.1 \%$ in cells at the different growth states, respectively.
Table IV. Release of $\left[{ }^{3} \mathrm{H}\right]$ Arachidonic Acid from Phospholipids Is Greater in Cells Passed to a Lower Density

\begin{tabular}{lcc}
\multicolumn{2}{l}{ Percentage of release of $\left[{ }^{3} \mathrm{H}\right.$ )arachidonic acid from phospholipids (mean $\pm \mathrm{SD}, n=3$ ) } \\
\hline Total & $1: 1$ split & $1: 3$ split \\
PC & $12.1 \pm 0.2$ & $26.4 \pm 1.1$ \\
PE & $14.0 \pm 0.7$ & $26.6 \pm 1.2$ \\
PI & $17.6 \pm 0.4$ & $27.9 \pm 1.3$ \\
PS & $0^{*}$ & $26.2 \pm 1.1$ \\
& $3.6 \pm 1.1$ & $15.5 \pm 3.3$
\end{tabular}

Confluent monolayers of bovine pulmonary artery endothelial cells were pulse labeled with $\left[{ }^{3} \mathrm{H}\right]$ arachidonic acid. $3 \mathrm{~d}$ after labeling, the cells were harvested (trypsin, EDTA) and replated at the original density (1:1) or at one-third density (1:3). $48 \mathrm{~h}$ later, the $1: 1$ split had resumed a tight, confluent monolayer and the 1:3 split was proliferating and had covered $\sim 50 \%$ of the culture plate surface. The cells were then exposed to buffer or buffer containing $10 \mu \mathrm{M} \mathrm{A23187} \mathrm{for} 1 \mathrm{~h}$ and the percentage of release of arachidonic acid was determined as described in Methods. Results shown are the mean and standard deviation of triplicate determinations in cells from a single isolate. For the control (unstimulated) flasks the mean total amount of $\left[{ }^{3} \mathrm{H}\right]$ arachidonic acid incorporated into cell lipids and the percentage of total label contained in each phospholipid were: for the $1: 1$ split, $126,900 \mathrm{dpm} /$ flask, PC $30.1 \%$, PI $12.9 \%$, PS 4.6\%, and PE 41.9\%; for the 1:3 split, 46,000 dpm/flask, PC $26.9 \%$, PI 11.3\%, PS 6.1\%, and PE 42.3\%. * The calculated release of [ $\left.{ }^{3} \mathrm{H}\right]$ arachidonic acid in this case was a negative number $(-7.5 \pm 1.9 \%)$, suggesting that label had chased into PI during stimulation.

Endothelial cells in vivo form a tightly confluent layer, which is important for its role as a barrier between blood and the tissues and would be analogous to the confluent phenotype in cultured cells. We asked whether the cells in the in vivo state displayed high or low release of arachidonic acid when stimulated. We placed a bovine pulmonary artery in a customdesigned template that we have described previously (3). In this circumstance the endothelium forms the floor of a plastic well the size of a cell culture dish but remains in situ on the blood vessel. Endothelial cells examined under these experimental conditions produced $151.5 \pm 8.3 \mathrm{ng}$ 6-keto $\mathrm{PGF}_{1 \alpha} / 10^{6}$ cells in response to calcium ionophore (10 $\mu \mathrm{M} \mathrm{A23187;60} \mathrm{min)} \mathrm{(}$ $=6$ ) which was nearly identical to that seen in confluent cultured cells (145.4 \pm 9.4 ng 6-keto $\mathrm{PGF}_{1 \alpha} / 10^{6}$ cells; $n=6$ ). Thus, we conclude that the arachidonic acid release phenotype is a function of the proliferative state of the cell and is reversed by changes in the growth state, such as the proliferative state that occurs in a quiescent monolayer after mechanical injury.

Characterization of the potential autocrine role of arachidonic acid metabolites and the cellular events involved in altered arachidonic acid release. We considered the possibility that endothelial cells released a soluble factor responsible for the decreasing release of arachidonic acid. We removed conditioned medium from cultures of confluent cells and placed it on preconfluent cells for the 24-h chase period after pulse-labeling with $\left[{ }^{3} \mathrm{H}\right]$ arachidonic acid. Upon stimulation, these cells released the same percentage of label from phospholipids as controls (not shown). Similarly, when labeled confluent cells were incubated in conditioned culture medium from preconfluent cells, the stimulated release of $\left[{ }^{3} \mathrm{H}\right]$ arachidonic acid was no different than control cultures (not shown). Thus, the observed changes could not be reproduced with a soluble factor. 


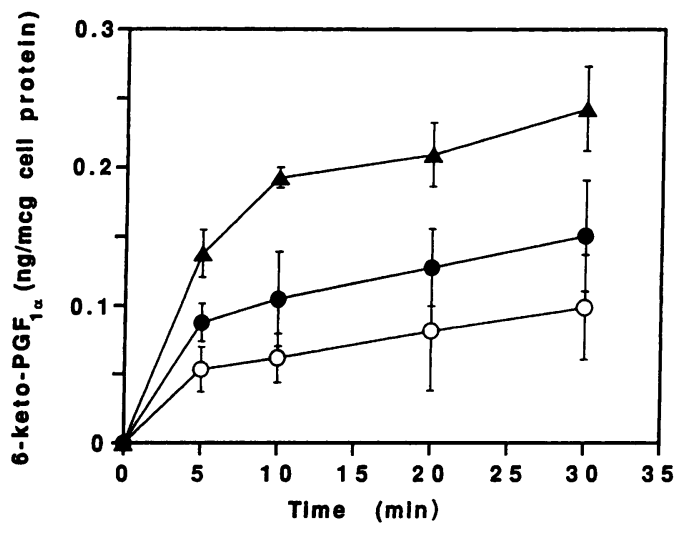

Figure 5. Stimulated production of $\mathrm{PGI}_{2}$ in endothelial cells proliferating after wounding of a confluent monolayer. Confluent monolayers of bovine endothelial cells were wounded by scraping with a sterile Teflon rake ( $\sim 0.25$-mm-wide prongs) in two directions perpendicular to each other, forming rectangular islands of cells $\sim 30$ cells across with adjacent furrows of approximately the same width. The wounded monolayers were then washed with growth medium and returned to fresh growth medium (triangles). Unwounded controls were treated in identical fashion (closed circles). Controls included a monolayer from which half of the cells had been removed in a "half-moon" pattern (open circles). Cells in the wounded monolayer began to proliferate and migrate into the wounded areas within $4 \mathrm{~h}$ and a confluent monolayer was reformed within 48-72 h; such proliferation and migration occurred in the halfmoon control but only in the limited population of cells at the border. At $8 \mathrm{~h}$ after wounding, growth medium was removed and replaced with buffer containing $10 \mu \mathrm{M}$ A23187 $\left(1 \mathrm{~h}\right.$ at $\left.37^{\circ} \mathrm{C}\right)$. The buffer was removed and assayed for $\mathrm{PGI}_{2}$ content. The amount of $\mathrm{PGI}_{2}$ per microgram of protein was calculated. The results are expressed as the amount of $\mathrm{PGI}_{2}$ produced in stimulated wounded cells compared with unwounded controls; the data represent the mean and range of duplicate determinations.

We next tested the possibility that the growth-dependent changes were a consequence of an autocrine process such as an arachidonic acid metabolite causing feedback inhibition of arachidonic acid release. Exposure of endothelial cells to $\mathrm{PGI}_{2}$, $\mathrm{PGE}_{2}$, or $\mathrm{PGF}_{2 \alpha}(100 \mathrm{ng} / \mathrm{ml})$, the major cyclooxygenase products in endothelial cells, or the stable $\mathrm{PGI}_{2}$ analogue, carbacyclin $(100 \mathrm{ng} / \mathrm{ml})$, did not inhibit the subsequent formation of prostacyclin in response to stimulation with calcium ionophore (not shown).

Given the striking growth-dependent alterations in arachidonic acid release and recent evidence that arachidonic acid metabolites may regulate growth or neoplasia, we next tested the possibility that endothelial cell proliferation was dependent on the formation of a cyclooxygenase product. Complete inhibition of endothelial cell cyclooxygenase by the addition of indomethacin $(10 \mu \mathrm{g} / \mathrm{ml})$ to growth medium did not inhibit the progression of the preconfluent culture to the contact-inhibited confluent monolayer (data not shown).

We next investigated the intracellular signaling events that might be responsible for the changes in arachidonic acid release. Elevations in intracellular calcium concentration play a central role in initiating arachidonic acid metabolism in endothelial cells, presumably by activating a $\operatorname{PLA}_{2}(7,26,31)$ (and/or other phospholipases). One potential explanation for the decreasing release as cells progressed to confluence was a loss of appropriate changes in intracellular calcium. This seemed an unlikely possibility since in these studies we used a maximal stimulus

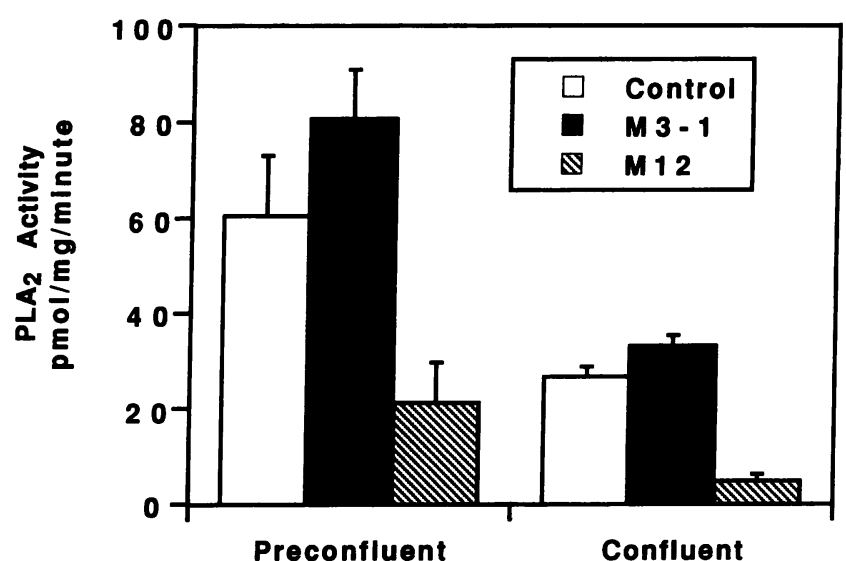

Figure 6. PLA $\mathrm{A}_{2}$ activity is greater in preconfluent endothelial cells than confluent cells. Preconfluent human umbilical vein endothelial cells ( 2 $\mathrm{d}$ after plating) were harvested and frozen for subsequent measurement of PLA $\mathrm{P}_{2}$ activity as described in Methods. Confluent endothelial cells ( $7 \mathrm{~d}$ after plating) from the same isolate were later harvested in identical fashion. Homogenates of the endothelial cells were prepared and incubated $\left(60 \mathrm{~min}\right.$ at $\left.4^{\circ} \mathrm{C}\right)$ with monoclonal antibodies $(1 \mathrm{mg} / \mathrm{ml})$ or with buffer control. (Monoclonal antibody M12 neutralizes PLA 2 activity; M3-1 binds to the PLA ${ }_{2}$ but does not inhibit its activity [46]. The small increase in activity seen with binding of M3-1 is similar to other reports [46].) After incubation with the antibodies or control, the amount of $\mathrm{PLA}_{2}$ activity was measured as hydrolysis of $\left[{ }^{3} \mathrm{H}\right]$ arachidonic acid from 1-stearoyl-2- $\left[{ }^{3} \mathrm{H}\right]$ arachidonoyl phosphatidylcholine. The activity is normalized to protein content and expressed as picomoles of substrate hydrolyzed per milligram of protein per minute. Measurements were performed in triplicate and expressed as the mean $\pm S D$. The results shown are from a single experiment.

(calcium ionophore $\mathrm{A} 23187,10 \mu \mathrm{M}, 1 \mathrm{~h}$ ) to eliminate potential differences such as growth-dependent differences in receptors. However, endothelial cells do have the capacity to rectify elevations in intracellular calcium, presumably via calcium ATPases present in the plasma membrane (or endoplasmic reticulum), or other sequestration mechanisms $(57,58)$. Consequently, we next tested the hypothesis that growth-dependent alterations in cellular handling of a calcium signal could be responsible for the differences in arachidonic acid release. Using Indo-1 spectrofluorimetry, ionophore-induced elevations in intracellular calcium were measured in single endothelial cells in sparse, preconfluent cultures and in confluent monolayers. There were no discernible quantitative or qualitative differences in the ionophore-induced response (not shown), indicating that growthdependent differences in calcium handling are not responsible for the differences in arachidonic acid metabolism at different growth states.

We next tested the hypothesis that the observed changes were a consequence of a change in phospholipase activity. It is generally believed that arachidonic acid is released from phospholipids either by a PLA ${ }_{2}$ or by the sequential action of a PLC followed by a diglyceride lipase. We measured PLA $\mathrm{A}_{2}$ and PLC activities in homogenates of cells at the different growth states. $\mathrm{PLA}_{2}$ activity in preconfluent cells was greater than that in confluent cells (Fig. 6). We found that PI-PLC activity, measured using PI as substrate, did not change during the progression from a preconfluent to a confluent state (not shown). In $\left[{ }^{3} \mathrm{H}\right]$ inositol-labeling studies we attempted to assess any differences in stimulated PI turnover as another measure of PI-PLC 


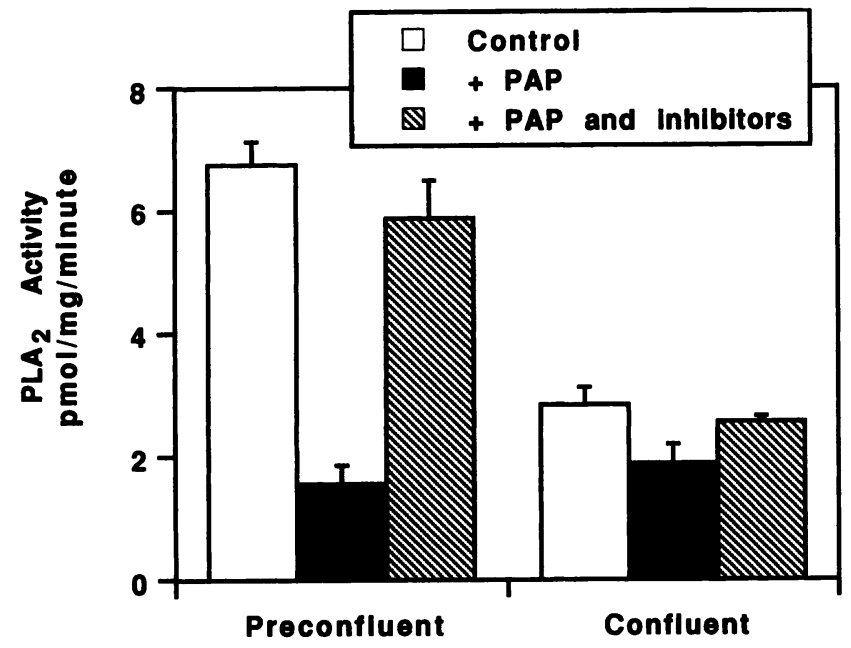

Figure 7. Phosphatase treatment reduces the amount of PLA $\mathrm{A}_{2}$ activity in preconfluent cells to that present in confluent cells. Preconfluent human umbilical vein endothelial cells ( $2 \mathrm{~d}$ after plating) were harvested and frozen for subsequent measurement of $\mathrm{PLA}_{2}$ activity as described in Methods. Confluent endothelial cells ( $7 \mathrm{~d}$ after plating) from the same isolate were later harvested in identical fashion. Homogenates of the endothelial cells were prepared and incubated with potato acid phosphatase $(P A P)\left(60 \mathrm{~min}\right.$ at $\left.30^{\circ} \mathrm{C}\right)$. Control incubations contained buffer or phosphatase in the presence of inhibitors $(50 \mathrm{mM} \mathrm{NaF}$ and $0.2 \mathrm{mM}$ $\mathrm{Na}_{3} \mathrm{VO}_{4}$ ). The incubation was terminated by the addition of fluoride and vanadate to those reactions not already containing them. The amount of PLA $\mathrm{P}_{2}$ activity in the homogenates was then assayed as described in Methods. The activity is normalized to protein content and expressed as picomoles of substrate hydrolyzed per milligram of protein per minute. Measurements were performed in triplicate and expressed as the mean $\pm S D$. The results shown are from a single experiment.

activity. As expected, stimulation with calcium ionophore resulted in rapid formation of inositol polyphosphates (data not shown) and there was no discernible difference between preconfluent and confluent cells. Consequently, only the changes in $\mathrm{PLA}_{2}$ activity were consistent with the growth-dependent differences in arachidonic acid release.

The decrease in the amount of $\mathrm{PLA}_{2}$ activity with the progression to confluence could have resulted from a decreased amount of enzyme or from a regulated change in the activity. Measurements of the amounts of the cytosolic PLA $\mathrm{A}_{2}$ in preconfluent and confluent cells by Western blotting showed no difference (not shown); in addition, the amounts of mRNA for this enzyme were no different at the different growth states when measured by PCR amplification (not shown). These data suggest that the differences in activity arise from a regulated change in the PLA $\mathrm{P}_{2}$ rather than differences in the amount of turnover of the enzyme. Recently several groups have shown that the PLA is regulated by phosphorylation $(46,59,60)$. To test whether differences in phosphorylation of the $\mathrm{PLA}_{2}$ were responsible for the changes that we observed, we treated endothelial cell homogenates with phosphatase and measured the residual PLA activity. Phosphatase treatment dramatically decreased the PLA $_{2}$ activity in homogenates from preconfluent cells (Fig. 7). Importantly, the activity in homogenates from preconfluent endothelial cells that remained after phosphatase treatment was approximately that found in homogenates of confluent cells (Fig. 7). To further confirm the differences in the regulation of $\mathrm{PLA}_{2}$ by phosphorylation, we exploited the observation by other
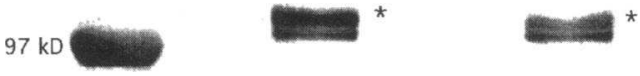

Figure 8. The phosphorylated form of $\mathrm{PLA}_{2}$ is in greater abundance in preconfluent endothelial cells than confluent cells. Preconfluent human umbilical vein endothelial cells ( $2 \mathrm{~d}$ after plating) were harvested, placed in SDS sample buffer, and frozen. Confluent endothelial cells ( $8 \mathrm{~d}$ after plating) from the same isolate were later harvested in identical fashion. Proteins were separated by SDS-PAGE ( $10 \%$ gel) with prolonged electrophoresis to separate the phosphorylated (higher apparent molecular mass, asterisk) from the nonphosphorylated form $(46,59)$. The proteins were then electrophoretically transferred to a polyvinyldifluoride membrane and subjected to immunoblotting using the monoclonal antibody M3-1. Although the relative amounts of the two forms of the PLA differed from isolate to isolate, the relative amount of the phosphorylated form was consistently greater in preconfluent cells compared with the confluent cells in five isolates examined.

workers that the phosphorylated form of the PLA $\mathrm{A}_{2}$ migrates less rapidly on SDS gel than the nonphosphorylated protein (46, 59). SDS-PAGE of preconfluent and confluent endothelial cell proteins, followed by Western blotting for the PLA 2 , demonstrated that the upper band (the phosphorylated form) was present in greater amounts in the preconfluent cells compared with the confluent cells (Fig. 8). These data indicate that the growthdependent differences in arachidonic acid release arise from a regulated alteration in the activity of the arachidonate-specific PLA $_{2}$ and that this regulation is a consequence of differences in phosphorylation, presumably a consequence of protein kinase(s) activity. This is consistent with other studies where we have found that the growth-dependent change in activity is consistent with a process regulated by PKC (61).

\section{Discussion}

We found that stimulated release of arachidonic acid and the consequent production of $\mathrm{PGI}_{2}$ decrease as cells progress to confluence in culture. This was demonstrated using both metabolic labeling with $\left[{ }^{3} \mathrm{H}\right]$ arachidonic acid and mass measurements including gas chromatography of arachidonic acid content and radioimmunoassay of the major arachidonic acid metabolite. The decrease in release occurred as cells progressed from a sparse, actively dividing culture to a quiescent, contactinhibited monolayer and related to the growth state of the cell as measured by cell cycle analysis. Control experiments demonstrated that the alteration in release of $\left[{ }^{3} \mathrm{H}\right]$ arachidonic acid was not a result of a difference in distribution of label at the different growth states and confirmed that arachidonic acid was not sequestered into a poorly mobilized pool. In fact, these studies demonstrate that arachidonic acid release from preconfluent cells was greater in each phospholipid and phospholipid subclass (compared with confluent cells). These data do not exclude the possibility that the arachidonic acid might be sequestered into a geographically defined pool within the cell. Currently, there is no way to directly test this possibility. However, the $\left[{ }^{3} \mathrm{H}\right]$ arachidonic acid-labeling studies demonstrate that uptake, distribution, and redistribution of label is identical in both preconfluent and confluent cells. If there were differences in the topographic distribution of arachidonic acid at the two growth 
states, one would predict that these distributions would also be different.

In other control experiments, we found, as others have (56), that a small percentage of the $\left[{ }^{3} \mathrm{H}\right]$ arachidonic acid is rapidly metabolized to $\left[{ }^{3} \mathrm{H}\right]$ docosatetraenoate. This conversion of arachidonic acid occurred to the same degree in both preconfluent and confluent cells; in addition, the docosatetraenoate was released in a fashion identical to arachidonic acid at both growth states. These data indicate that differences in conversion of label are not responsible for the differences in the stimulated release of $\left[{ }^{3} \mathrm{H}\right]$ arachidonic acid at the different growth states. Moreover, the growth-dependent differences in arachidonic acid release were seen when arachidonic acid content was measured by gas chromatography, a measurement that is not affected by metabolism of label.

All of these studies indicate that the changes in the stimulated release of arachidonic acid arise from a regulated change within the cell, occurring at the initial release of arachidonic acid from its phospholipid storage site. As arachidonic acid is selectively esterified at the $s n-2$ position of phospholipids, the

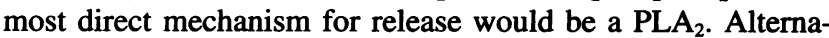
tively, sequential action of a PLC and diglyceride lipase $(7,25)$ or PLD, phosphatidic acid phosphatase and a diglyceride lipase $(7,29)$ would also result in arachidonic acid release. PLC activity did not change significantly at the different growth states;

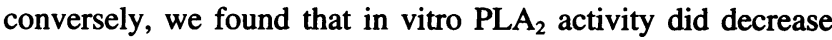
in concert with the decreased release measured in metabolic labeling studies. Although phospholipase activity measured by an optimized in vitro assay may not reflect the activity in the whole cell where a variety of factors (e.g., substrate concentration, cofactors) are likely be different than in an in vitro assay, our results are consistent with the possibility that the differences in arachidonic acid release and $\mathbf{P G I}_{2}$ formation at the different

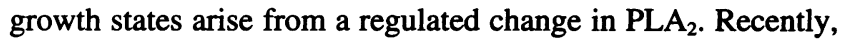
several groups have purified and cloned a calcium-dependent cytoplasmic PLA $\mathrm{P}_{2}$ that is an attractive candidate for the enzyme responsible for arachidonic acid release in several cell types $(30,33,34)$. Currently, the mechanisms that regulate the activity of this enzyme are incompletely understood, although there is increasing evidence that this step is regulated by phosphorylation, a step involving PKC, probably in concert with other protein kinases $(59,60)$, particularly mitogen-activated protein kinase $(62,63)$. Our data presented here and previous data that are consistent with a regulatory role for PKC in this process (61) are all consistent with that hypothesis.

Increased formation of arachidonic acid metabolites could be an important response under circumstances in which rapid growth of endothelial cells occurs, such as after vascular damage. Our results indicate that the increased arachidonic acid release is an intrinsic property of proliferating endothelial cells. Prolonged prostacyclin formation has been demonstrated in animal models of vascular injury $(64,65)$, suggesting that our observations in cultured cells may well be important in that setting. Moreover, we have preliminary results that demonstrate that this phenomenon is present in other cells of mesothelial origin (our unpublished data). This may be relevant to the observation that some forms of rapidly proliferating cells, colon polyps (10) and perhaps colon cancers (11), depend on prostaglandins as a growth signal. Our data exclude such an autocrine role for $\mathrm{PGI}_{2}, \mathrm{PGE}_{2}$, or $\mathrm{PGF}_{2 \alpha}$ as feedback inhibitors of arachidonic acid release; conversely, inhibition of the cyclooxygenase pathway in these cells (and the consequent inhibition of a basal formation of cyclooxygenase products) did not affect cell proliferation. However, these data do not exclude an autocrine role for arachidonic acid metabolites produced by pathways other than cyclooxygenase (e.g., hydroxyeicosatetraeonic acid, hydroperoxyeicosatetraenoic acids). In addition to cyclooxygenase, other pathways for arachidonic acid (and other long chain unsaturated fatty acids) metabolism are present in endothelial cells and regulatory roles for several of these products have been proposed $(7,66,67)$.

\section{Acknowledgments}

We gratefully appreciate the technical assistance of Donelle Benson, Eric Stroud, David Burnett, and Mark Harrison.

This work was supported by a Merit Review Grant from the Department of Veterans Affairs Medical Research Program, the Nora Eccles Treadwell Foundation, and National Institutes of Health grants HL43689, HL-34127, HL-50153, and F32 HL-07529. Ralph Whatley has a Career Investigator Award from the American Lung Association. Guy A. Zimmerman and Stephen M. Prescott were Established Investigators of the American Heart Association during a portion of this work.

\section{References}

1. Alhenc-Gelas, F., S. J. Tsai, K. S. Callahan, W. B. Campbell, and A. R. Johnson. 1982. Stimulation of prostaglandin formation by vasoactive mediators in cultured human endothelial cells. Prostaglandins. 24:723-742.

2. Revtyak, G. E., A. R. Johnson, and W. B. Campbell. 1988. Cultured bovine coronary arterial endothelial cells synthesize HETEs and prostacyclin. Am. J. Physiol. 254:C8-C19.

3. Whatley, R. E., G. A. Zimmerman, T. M. McIntyre, and S. M. Prescott 1988. Endothelium from diverse vascular sources synthesizes platelet-activating factor. Arteriosclerosis. 8:321-331.

4. Jaffe, E. A., J. Grulich, B. B. Weksler, G. Hampel, and K. Watanabe. 1987. Correlation between thrombin-induced prostacyclin production and inositol trisphosphate and cytosolic free calcium levels in cultured human endothelial cells. J. Biol. Chem. 262:8557-8565.

5. Gerritsen, M. E. 1987. Functional heterogeneity of vascular endothelial cells. Biochem. Pharmacol. 36:2701-2711.

6. Gryglewski, R. J., R. M. Botting, and J. R. Vane. 1988. Mediators produced by the endothelial cell. Hypertension (Dallas). 12:530-548.

7. Whatley, R. E., G. A. Zimmerman, T. M. McIntyre, and S. M. Prescott. 1990. Lipid metabolism and signal transduction in endothelial cells. Prog. Lipid Res. 29:45-63.

8. Ristimaki, A., O. Ylikorkala, and L. Viinikka. 1989. Effect of growth factors on human vascular endothelial cell prostacyclin production. Arteriosclerosis. 10:653-657.

9. Hyman, B. T., L. L. Stoll, and A. A. Spector. 1982. Prostaglandin production by 3T3-L1 cells in culture. Biochim. Biophys. Acta. 713:375-385.

10. Rigau, J., J. M. Pique, E. Rubio, R. Planas, J. M. Tarrech, and J. M. Bordas. 1991. Effects of long-term sulindac therapy on colonic polyposis. Ann. Intern. Med. 115:952-954.

11. Skinner, S. A., A. G. Penney, and P. E. O'Brien. 1991. Sulindac inhibits the rate of growth and appearance of colon tumors in the rat. Arch. Surg. 126:1094-1096.

12. Patte, C., and P. R. Blanquet. 1992. Possible involvement of arachidonic acid metabolites in the synergistic action of endothelial cell mitogenesis by basic fibroblast growth factor and phorbol ester. Cell. Mol. Biol. 38:429-436.

13. Jones, D. A., D. P. Carlton, T. M. McIntyre, G. A. Zimmerman, and S. M. Prescott. 1993. Molecular cloning of human prostaglandin endoperoxide synthase type II and demonstration of expression in response to cytokines. J. Biol. Chem. 268:9049-9054.

14. Evans, C. E., D. Billington, and F. A. McEvoy. 1984. Prostacyclin production by confluent and non-confluent human endothelial cells in culture. Prostaglandins Leukotrienes Med. 14:255-266.

15. Ingerman-Wojenski, C. M., M. J. Silver, S. N. Mueller, and E. M. Levine. 1988. Prostacyclin synthesis by endothelial cells from human umbilical veins: effect of cumulative population doublings. Prostaglandins. 36:127-137.

16. Goldsmith, J. C., J. J. McCormick, and A. Yen. 1984. Endothelial cell cycle kinetics. Lab. Invest. 51:643-647.

17. Spector, A. A., J. C. Hoak, G. L. Fry, L. L. Stoll, C. T. Tanke, and T. L. Kaduce. 1981. Essential fatty acid availability and prostacyclin production by cultured human endothelial cells. Prog. Lipid Res. 20:471-477. 
18. Hong, S. L. 1988. The release of arachidonic acid from cellular lipids. Prog. Allergy. 44:99-139.

19. Johnson, A. R., G. Revtyak, and W. B. Campbell. 1985. Arachidonic acid metabolites and endothelial injury: studies with cultures of human endothelial cells. Fed. Proc. 44:19-24.

20. Hong, S. L., N. J. McLaughlin, C. -y. Tzeng, and G. Patton. 1985. Prostacyclin synthesis and deacylation of phospholipids in human endothelial cells comparison of thrombin, histamine and ionophore A23187. Thromb. Res. 38:110.

21. Holub, B. J., and P. W. Kuksis. 1978. Metabolism of molecular species of diacylglycerophospholipids. Adv. Lipid Res. 16:1-125.

22. Nieto, M. L., M. E. Venable, S. A. Bauldry, D. G. Greene, M. Kennedy, D. A. Bass, and R. L. Wykle. 1991. Evidence that hydrolysis of ethanolamine plasmalogens triggers synthesis of platelet-activating factor via a transacylation reaction. J. Biol. Chem. 266:18699-18706.

23. Snyder, F., Y. Uemura, and T-c. Lee. 1991. A coenzyme A-independen transacylase is linked to the formation of platelet-activating factor (PAF) by generating the lyso-PAF intermediate in the remodeling pathway. J. Biol. Chem. 266:8268-8272.

24. Prescott, S. M., and P. W. Majerus. 1983. Characterization of 1,2-diacylglycerol hydrolysis in human platelets. J. Biol. Chem. 258:764-769.

25. Bell, R. L., D. A. Kennerly, N. Stanford, and P. W. Majerus. 1979. Diglyceride lipase: a pathway for arachidonate release from human platelets. Proc. Natl. Acad. Sci. USA. 76:3238-3241.

26. Whorton, A. R., C. E. Willis, R. S. Kent, and S. L. Young. 1984. The role of calcium in the regulation of prostacyclin synthesis by porcine aortic endothelial cells. Lipids. 19:17-24.

27. Lambert, T. L., R. S. Kent, and A. R. Whorton. 1986. Bradykinin stimulation of inositol polyphosphate production in porcine aortic endothelial cells. $J$. Biol. Chem. 261:15288-15293.

28. Haldorsson, H., M. Kjeld, and G. Thorgeirsson. 1988. Role of phosphoinositides in the regulation of endothelial prostacyclin production. Arteriosclerosis 8:147-154.

29. Martin, T. W., and K. C. Michaelis. 1988. Bradykinin stimulates phosphodiesteric cleavage of phosphatidylcholine in cultured endothelial cells. Biochem Biophys. Res. Commun. 157:1271-1279.

30. Alonso, F., P. M. Henson, and C. C. Leslie. 1986. A cytosolic phospholipase in human neutrophils that hydrolyzes arachidonoyl-containing phosphatidylcholine. Biochim. Biophys. Acta. 878:273-280.

31. Leslie, C. C., D. R. Voelker, J. Y. Channon, M. M. Wall, and P. T Zelarney. 1988. Properties and purification of an arachidonoyl-hydrolyzing phospholipase $\mathbf{A}_{2}$ from a macrophage cell line, RAW 264.7. Biochim. Biophys. Acta. 963:476-492.

32. Channon, J. Y., and C. C. Leslie. 1990. A calcium-dependent mechanism for associating a soluble arachidonoyl-hydrolyzing phospholipase $A_{2}$ with membrane in the macrophage cell line RAW 264.7. J. Biol. Chem. 265:5409-5413.

33. Clark, J. D., L. L. Lin, R. W. Kriz, C. S. Ramesha, L. A. Sultzman, A. Y Lin, N. Milona, and J. L. Knopf. 1991. A novel arachidonic acid-selective cytosolic PLA2 contains a $\mathrm{Ca}^{2+}$-dependent translocation domain with homology to PKC and GAP. Cell. 65:1043-1051.

34. Sharp, J. D., D. L. White, X. G. Chiou, T. Goodson, G. C. Gamboa, D. McClure, S. Burgett, J. Hoskins, P. L. Skatrud, J. R. Sportsman, et al. 1991 Molecular cloning and expression of human $\mathrm{Ca}^{++}$-sensitive cytosolic phospholipase A. J. Biol. Chem. 266:14850-14853.

35. Kramer, R. M., E. F. Roberts, J. Manetta, and J. E. Putnam. 1991. The $\mathrm{Ca}^{2+}$-sensitive cytosolic phospholipase $\mathrm{A}_{2}$ is a $100-\mathrm{kDa}$ protein in human monoblast U937 cells. J. Biol. Chem. 266:5268-5272.

36. Whatley, R. E., P. Nelson, G. A. Zimmerman, D. L. Stevens, C. J. Parker, T. M. McIntyre, and S. M. Prescott. 1989. The regulation of platelet-activating factor production in endothelial cells: the role of calcium and protein kinase C. J. Biol. Chem. 264:6325-6333.

37. Zavoico, G. B., J. K. Hrbolich, M. A. Gimbrone, and A. I. Schafer. 1990 Enhancement of thrombin- and ionomycin-stimulated prostacyclin and plateletactivating factor production in cultured endothelial cells by a tumor-promoting phorbol ester. J. Cell. Physiol. 143:596-605.

38. Garcia, M. C., H. W. Mueller, and M. D. Rosenthal. 1991. C20 polyunsaturated fatty acids and phorbol myristate acetate enhance agonist-stimulated synthesis of 1-radyl-2-acetyl-sn-glycero-3-phosphocholine in vascular endothelial cells. Biochim. Biophys. Acta. 1083:37-45.

39. Zimmerman, G. A., R. E. Whatley, T. M. McIntyre, D. M. Benson, and S. M. Prescott. 1990. Endothelial cells for studies of platelet-activating factor and arachidonate metabolites. In Methods in Enzymology. R. C. Murphy and F. A. Fitzpatrick, editors. Academic Press, Inc., San Diego. 520-535.

40. Satoh, K., and S. M. Prescott. 1987. Culture of mesothelial cells from bovine pericardium and characterization of their arachidonate metabolism. Bio chim. Biophys. Acta. 930:283-296.

41. Lowry, O. H., N. J. Rosebrough, A. L. Farr, and R. J. Randall. 1951. Protein measurement with the Folin phenol reagent. J. Biol. Chem. 193:265-275.
42. Bligh, E. G., and W. J. Dyer. 1959. A rapid method of total lipid extraction and purification. Can. J. Biochem. Physiol. 37:911-917.

43. Ames, B., and D. T. Dubin. 1960. The role of polyamines in the neutralization of bacteriophage deoxyribonucleic acid. J. Biol. Chem. 235:769-775.

44. Patton, G. M., J. M. Fasulo, and S. J. Robins. 1982. Separation of phospholipids and individual molecular species of phospholipids by high-performance liquid chromatography. J. Lipid Res. 23:190-196.

45. Blank, M. L., E. A. Cress, and F. Snyder. 1987. Separation and quantitation of phospholipid subclasses as their diradylglycerobenzoate derivatives by normal phase high-performance liquid chromatography. J. Chromatogr. 392:421-425.

46. Kramer, R. M., E. F. Roberts, J. V. Manetta, P. A. Hyslop, and J. A Jakubowski. 1993. Thrombin-induced phosphorylation and activation of $\mathrm{Ca}^{++}$ sensitive cytosolic phospholipase $\mathrm{A}_{2}$ in human platelets. J. Biol. Chem. 268:26796-26804

47. Hoffman, S. L., and P. W. Majerus. 1982. Modulation of phosphatidylinositol-specific phospholipase $\mathrm{C}$ activity by phospholipid interactions, diglycerides and calcium ions. J. Biol. Chem. 257:14359-14364.

48. Harlow, E., and D. Lane. 1988. Antibodies: A Laboratory Manual. Cold Spring Harbor Laboratory, Cold Spring Harbor, NY. 471-510.

49. Sambrook, J., E. F. Fritsch, and T. Maniatis. 1989. Molecular Cloning: A Laboratory Manual. Cold Spring Harbor Laboratory, Cold Spring Harbor, NY.

50. Yokoyama, C., and T. Tanabe. 1989. Cloning of human gene encoding prostaglandin endoperoxide synthase and primary structure of the enzyme. Biochem. Biophys. Res. Commun. 165:888-894.

51. DeWitt, D. L., E. A. el-Harith, and W. L. Smith. 1989. Molecular cloning of prostaglandin G/H synthase. Adv. Prostaglandin Thromboxane Leukotriene Res. 19:454-457.

52. Fagan, D., J. Merlie, N. Siegel, A. Raz, J. Mudd, and P. Needleman. 1989. Complementary DNA clone for sheep seminal vesicle prostaglandin endoperoxide synthase (cyclooxygenase). Adv. Prostaglandin Thromboxane Leukotriene Res. 19:42-48.

53. Tso, J. Y., X.-H. Sun, T.-H. Kao, K. S. Reece, and R. Wu. 1985. Isolation and characterization of rat and human glyceraldehyde-3-phosphate dehydrogenase cDNAs: genomic complexity and molecular evaluation of the gene. Nucleic Acids Res. 13:2485-2502.

54. Takayama, H., M. H. Kroll, M. A. Gimbrone, and A. I. Schaefer. 1989. Turnover of eicosanoid precursor fatty acids among phospholipid classes and subclasses of cultured human umbilical vein endothelial cells. Biochem. $J$ 258:427-434.

55. Wey, H. E., J. A. Jakubowski, and D. Deykin. 1986. Incorporation and redistribution of arachidonic acid in diacyl and ether phospholipids of bovine aortic endothelial cells. Biochim. Biophys. Acta. 878:380-386.

66. Spector, A. A., T. L. Kaduce, J. C. Hoak, and G. L. Fry. 1981. Utilization of arachidonic and linoleic acids by cultured human endothelial cells. J. Clin. Invest. 68:1003-1011.

57. Schilling, W. P., L. Rajan, and E. Strobl-Jager. 1989. Characterization of the bradykinin-stimulated calcium influx pathway of cultured vascular endothelia cells. J. Biol. Chem. 264:12838-12848.

58. Jacob, R. 1990. Agonist-stimulated divalent cation entry into single cultured umbilical vein endothelial cells. J. Physiol. (Camb.). 421:55-77.

59. Lin, L.-L., A. Y. Lin, and J. L. Knopf. 1992. Cytosolic phospholipase $A_{2}$ is coupled to hormonally regulated release of arachidonic acid. Proc. Natl. Acad. Sci. USA. 89:6147-6151.

60. Wijkander, J., and R. Sundler. 1992. Regulation of arachidonate-mobilizing phospholipase $A_{2}$ by phosphorylation via protein kinase $C$ in macrophages. FEBS (Fed. Eur. Biochem. Soc.) Lett. 311:299-301.

61. Whatley, R. E., E. D. Stroud, M. Bunting, G. A. Zimmerman, T. M. McIntyre, and S. M. Prescott. 1993. Growth-dependent changes in arachidonate release from endothelial cells are mediated by protein kinase $\mathrm{C}$ and changes in diacylglycerol. J. Biol. Chem. 268:16130-16138.

62. Lin, L.-L., M. Wartmann, A.-Y. Lin, J. L. Knopf, A. Seth, and R. J. Davis. 1993. cPLA2 is phosphorylated and activated by MAP kinase. Cell. 72:269-278.

63. Durstin, M., S. Durstin, T. F. P. Molski, E. L. Becker, and R. I. Sha'afi. 1994. Cytoplasmic phospholipase A2 translocates to membrane fraction in human neutrophils activated by stimuli that phosphorylate mitogen-activated protein kinase. Proc. Natl. Acad. Sci. USA. 91:3142-3146.

64. Meyrick, B., R. J. Workman, M. G. Frazer, M. Okamoto, J. E. Hazlewood, and K. L. Brigham. 1985. Endothelial prostacyclin production is a late even in granulocyte migration into bovine pulmonary artery intimal implants. Blood. 66:1379-1383.

65. Watkins, W. D., P. C. Huttemeier, D. Kong, and M. B. Peterson. 1982. Thromboxane and pulmonary hypertension following $E$. coli endotoxin infusion in sheep: effect of an imidazole derivative. Prostaglandins. 23:273-285.

66. Hopkins, N. K., T. D. Oglesby, G. L. Bundy, and R. R. Gorman. 1984. Biosynthesis and metabolism of 15-hydroperoxy-5,8,11,13-eicosatetraenoic acid by human umbilical vein endothelial cells. J. Biol. Chem. 259:14048-14053

67. Kaduce, T. L., P. H. Figard, R. Leifur, and A. A. Spector. 1989. Formation of 9-hydroxyoctadecadienoic acid from linoleic acid in endothelial cells. J. Biol. Chem. 264:6823-6830. 